\title{
Silver Nanoparticles Synthesized with Rumex hymenosepalus: A Strategy to Combat Early Mortality Syndrome (EMS) in a Cultivated White Shrimp
}

\author{
Francisco Javier Alvarez-Cirerol, ${ }^{1}$ Marco Antonio López-Torres, ${ }^{1}$ Ericka Rodríguez-León, ${ }^{2}$ \\ César Rodríguez-Beas, ${ }^{2}$ Aaron Martínez-Higuera, ${ }^{2}$ Humberto H. Lara ${ }^{D},{ }^{3}$ Sandra Vergara, ${ }^{3}$ \\ M. Josefina Arellano-Jimenez $\mathbb{D},{ }^{3}$ Eduardo Larios-Rodríguez $\mathbb{D},{ }^{4}$ Marcel Martínez-Porchas, ${ }^{5}$ \\ Enrique de-la-Re- Vega, ${ }^{1}$ and Ramón Alfonso Iñiguez-Palomares $\mathbb{D}^{2}$ \\ ${ }^{I}$ Departamento de Investigaciones Científicas y Tecnológicas de la Universidad de Sonora, Blvd. Rosales s/n. Centro, \\ CP 83110 Hermosillo, Sonora, Mexico \\ ${ }^{2}$ Departamento de Física, Universidad de Sonora, Blvd. Rosales s/n. Centro, CP 83110 Hermosillo, Sonora, Mexico \\ ${ }^{3}$ Department of Physics and Astronomy, University of Texas at San Antonio, San Antonio TX 78249, USA \\ ${ }^{4}$ Departamento de Ingeniería Química y Metalurgia, Universidad de Sonora, Blvd. Rosales s/n. Centro, CP 83110 Hermosillo, \\ Sonora, Mexico \\ ${ }^{5}$ Centro de Investigación en Alimentación y Desarrollo A.C., Hermosillo, Sonora, Mexico
}

Correspondence should be addressed to Ramón Alfonso Iñiguez-Palomares; ramonalfonso.iniguez@gmail.com

Received 21 March 2019; Revised 8 July 2019; Accepted 25 July 2019; Published 8 September 2019

Academic Editor: Mohamed Bououdina

Copyright (c) 2019 Francisco Javier Alvarez-Cirerol et al. This is an open access article distributed under the Creative Commons Attribution License, which permits unrestricted use, distribution, and reproduction in any medium, provided the original work is properly cited.

\begin{abstract}
Early Mortality Syndrome (EMS) or Acute Hepatopancreatic Necrosis Syndrome (AHPNS) is a disease produced by gram-negative bacteria Vibrio parahaemolyticus ( $V$. parahaemolyticus), which has caused declines in worldwide production of a white shrimp Litopenaeus vannamei (L. vannamei). In this work, we propose the implementation of silver nanoparticles (AgNPs) synthesized with Rumex hymenosepalus (Rh) extract as an alternative on $V$. parahaemolyticus control. AgNPs were characterized by UV-Vis spectroscopy, scanning electron microscopy (SEM), transmission electron microscopy (TEM), and selected area electron diffraction (SAED). AgNP mean sizes by DLS were $80.82 \pm 1.16 \mathrm{~nm}$ and sizes between 2 and $10 \mathrm{~nm}$ by TEM, with a zeta potential of $-47.72 \pm 1.05 \mathrm{mV}$. This study evaluated AgNPs and Rh antimicrobial capacity on $V$. parahaemolyticus at different concentrations; the minimum inhibitory concentration (MIC) found was $25 \mu \mathrm{g} / \mathrm{mL}$ for AgNPs and $220 \mu \mathrm{g} / \mathrm{mL}$ for Rh. Additionally, were carried out time-kill curves and reactive oxygen species (ROS) generation for 1 and 4 MIC. Both concentrations (MIC) were tested for toxicity on Artemia nauplii from Artemia franciscana (A. franciscana), because nauplii were used as biocarriers for AgNPs and Rh extract on L. vannamei. Once the shrimp were treated, they were challenged with Vibrio infection and it was found that those who were treated with both agents showed greater survival than the control. $V$. parahaemolyticus and postlarval samples were taken from the bioassay and fixed and prepared for TEM and SEM in order to search NPs in internal structure of bacteria and the hepatopancreatic area of shrimps; AgNPs were detected in both cases. AgNPs and Rh extract show antibacterial properties on the infected shrimp with $V$. parahaemolyticus. The action mechanisms are interaction with the bacterial membrane and ROS generation; these effects are produced by both agents.
\end{abstract}

\section{Introduction}

Vibrio is a bacterium belonging to the genus that is gramnegative. Several species of this bacteria can cause food- borne infection, usually associated with seafood [1-4]. In 2013, a laboratory infection model found that a pathogenic strain of $V$. parahaemolyticus provokes an AHPNS illness, disease that has affected severely shrimp industry, because 
it can infect wild and cultivated shrimps [5-7]. This disease was detected for the first time in China in 2009, where a loss of $80 \%$ was reported in relation to the total production of the shrimp. The disease spread quickly and appeared in Vietnam (2010), Malaysia (2011), Thailand (2012), and even Mexico (2013) [8-11]. The most noticeable symptoms of the disease are an empty and atrophied intestine that presents a pale tone. Hepatopancreas histopathology shows inflammation and desquamation, while a hemocytic infiltrate is noted. This damage is produced by toxins PirAvp and PirBvp which have a structural similarity to B. thuringiensis Cry pore-forming toxin, so it has been suggested that PirAvp/PirBvp promote a similar process to induce cell death of the hepatopancreas tissue in shrimps $[12,13]$. Several strategies have been addressed to control diseases that affect a shrimp, such as tank water replacements, good personnel management practices, water monitoring, and use of antibiotics. However, these measures have not been enough for the control and elimination of bacteria, and moreover, an increase in resistant organisms has also been reported [14, 15].

On the one hand, given the inefficiency of conventional treatments, the development of new agents for pathogen treatment has been opted for, such as nanomaterial development and implementation, including antibiotic resistance $[16,17]$. On the other hand, green synthesis is a viable strategy for nanomaterial generation, since it is a process that uses plant extracts, algae, fungi, yeast, etc., as reducing agents, and is safe and an eco-friendly strategy $[18,19]$. In particular, $\mathrm{Rh}$ is a plant species that radices in Northwest of Mexico and Southwest of United States and ethanolic, its extract from $\mathrm{Rh}$, has been utilized for AgNP synthesis, in nanotechnology field, highlighting how this has shown a very promising effect as a bactericide $[3,20,21]$. In this work, we propose to control AHPN in L. vannamei at a postlarval stage, using Artemia salina (A. salina) as a vector for AgNPs and Rh.

Nauplii (a larval stage of Artemia) have been used as biocarriers for feeding in diverse species such as coral, fish, and shrimp [22, 23], for the encapsulation of supplements as probiotics, prebiotics, and symbiotic [24], for antibiotics [25], vaccines [26], and liposomes [27]. In addition, nauplii are used to transport inorganic $\left(\mathrm{CuO}, \mathrm{Ag}, \mathrm{TiO}_{2}\right.$, and $\left.\mathrm{AgTiO}_{2}\right)$ nanomaterials; in general, nauplii can be used as biological model nanotoxicology assays [28-32]. Other biocarriers for metallic NP include yeast cells (Ag and Pd) [10], magnetotactic bacteria [33], and bacterial ghost, which uses only some functions of microorganisms to transport nanomaterials as the outer membrane of gram-negative bacteria [34]. Nauplii are used as a biocarrier and toxicology assay before the test in a shrimp.

In this work, we synthesized AgNPs with Rh extract as a reductor agent. AgNPs and Rh extract in vitro evaluate antimicrobial activity against $V$. parahaemolyticus, and MIC was determined by $96-$-well plate microdilution assay. The timekill experiments were performed to determine the bactericidal capacity of agents. Artemia nauplii were used like vectors of AgNPs and Rh extract to feed shrimp postlarvae with the goal to evaluate the microbicide effect of these materials in V. parahaemolyticus infection.

\section{Experimental}

2.1. Synthesis of NPs. Rh extract was obtained according to the protocol previously reported by our group [20] and subsequently lyophilized and refrigerated until its use. For nanoparticle synthesis, an aqueous solution of the lyophilized extract was prepared at concentration of $11.6 \mathrm{mg} / \mathrm{mL}$ and then $16 \mathrm{~mL}$ of extract solution was added to $8 \mathrm{~mL}$ of silver nitrate (Sigma-Aldrich $99.9 \%$ ) at $0.1 \mathrm{M}$ and $64 \mathrm{~mL}$ of ultrapure water with resistance of $18.2 \mathrm{M} \Omega$ as solvent. Mixture was prepared in a $100 \mathrm{~mL}$ clear glass flask and stirred with a magnet on a stir plate for one hour in the presence of sunlight to promote synthesis. Color of the solution changed from a reddish brown color to a dark brown color after synthesis. Sunlight radiation in Hermosillo, México, has a beam normal solar radiation of $7.8 \mathrm{kWh} / \mathrm{m}^{2} /$ day [35]. Once synthesized, NPs were cleaned to remove the remaining reactants by the following procedure: centrifugation at 15,000 rpm (Thermo Scientific/Sorvall model Legend X1), removal of supernatant, resuspension of the NP pellet in ultrapure water, and sonication for $30 \mathrm{~min}$ (Branson, ultrasonic 2800). The process was repeated 3 times, and pellet obtained on last step was dried in an oven at $40^{\circ} \mathrm{C}$ for $12 \mathrm{~h}$. Solids recovered were weighed and resuspended by sonication for $3 \mathrm{~h}$ in ultrapure water to obtain stock solution of AgNPs.

2.2. UV-Vis Spectroscopy. Spectroscopy was performed in a PerkinElmer Lambda 40 double-beam spectrophotometer at a range of 900 to $200 \mathrm{~nm}$, a step speed of $480 \mathrm{~nm}$ per min at $25^{\circ} \mathrm{C}$, and a beam aperture width of $0.5 \mathrm{~nm}$. Ultrapure water was used as a blank reference for NPs and Rh extract.

2.3. Dynamic Light Scattering. AgNP sizes were measured by dynamic light scattering (DLS) of Zetasizer Nano ZS (Malvern Instruments, UK) with resolution of $0.5 \mathrm{~nm}$ and sensitivity of $0.1 \mathrm{mg} / \mathrm{mL}$. The instrument determines the size by first measuring the Brownian motion of particles in the samples using DLS and interpreting a size from this using the established theories. The relationship between particle size and its speed due to Brownian motion is defined in the Stokes-Einstein equation.

$$
D=\frac{K_{\mathrm{B}} T}{6 \pi \eta R},
$$

where $D$ is the diffusion coefficient, $K_{\mathrm{B}}$ is the Boltzmann constant, $T$ is the temperature of the sample, $\eta$ is the viscosity, and $R$ is the hydrodynamic radio, which represent particle size in $\mathrm{nm}$. Each sample was measured at room temperature $\left(25^{\circ} \mathrm{C}\right)$ in triplicate.

2.4. Zeta Potential and Conductivity $(\sigma) . \zeta$ and $\sigma$ of AgNP solutions were measured by using a Zetasizer Nano ZS (Malvern Instruments, UK). The instrument calculates the $\zeta$ by determining the electrophoretic mobility $\left(\mu_{\mathrm{e}}\right)$ using the Henry equation [36]:

$$
\mu_{e}=\frac{2 \varepsilon z f(k a)}{3 \eta},
$$


where $z, \varepsilon, \eta$, and $f(k a)$ denote the $\zeta$, media dielectric constant, media viscosity, and Henry's function, respectively. Two values are generally used as approximations for the $f(k a)$ determination, either 1.5 or 1.0. Electrophoretic determination of $\zeta$ is most commonly made in aqueous solvent and moderate electrolyte concentration. $f(\mathrm{ka})$, in this case, takes the value of 1.5 and is referred to as the classical Smoluchowski approximation [37].

$$
\alpha=\varepsilon \frac{z}{\eta} .
$$

Samples were placed into a U-shaped folded capillary cell for $\zeta$ measurements. Each sample was measured at room temperature $\left(25^{\circ} \mathrm{C}\right)$ in triplicate.

2.5. FT-IR. Fourier transform IR spectroscopy experiments were performed on a PerkinElmer FT-IR, System Spectrum GX. Spectra were obtained in transmittance mode in the region comprised between 4000 and $500 \mathrm{~cm}^{-1}$, at a resolution of $0.3 \mathrm{~cm}^{-1}$.

2.6. TEM and SEM. AgNP characterization was carried out in a field emission JEOL microscope, model 2010F. The equipment has a spherical aberration corrector that allows a point-to-point spatial resolution of $0.19 \mathrm{~nm}$. The operating voltage was $200 \mathrm{kV} .10 \mu \mathrm{L}$ of NPs was deposited on a formvar/carbon copper (EMS) TEM grid (300 mesh) coated with a carbon film as support. The sample was left to dry on the grid at room temperature until the solvent evaporated $(12 \mathrm{~h})$ and then stored in an Eppendorf tube $(1.5 \mathrm{~mL})$ until it was observed. TEM and SEM were performed using a FEG (Hitachi S-5500), an ultrahigh resolution electron microscope $(0.4 \mathrm{~nm}$ at $30 \mathrm{kV})$ with a BF/DF Duo-STEM detector.

2.7. Sample Preparation by Ultramicrotomy. TEM and SEM were performed using a FEG (Hitachi S-5500), as described before. In the analysis of glutaraldehyde-fixed organisms, a petri dish was used, under an extraction hood to obtain the hepatopancreas using a scalpel. Tissue sections were placed in $2 \mathrm{~mL}$ Eppendorf tubes, and two consecutive washes were made with PBS (phosphate-buffered saline) for $15 \mathrm{~min}$ each. Subsequently, PBS 1x was removed and a solution of $1 \%$ osmium tetroxide $\left(\mathrm{OsO}_{4}\right)$ in $\mathrm{PBS}$ was deposited in the tube for $1 \mathrm{~h}$ to stain the tissue sample to be observed by TEM and SEM. $\mathrm{OsO}_{4}$ was removed, and two PBS washes were made for $15 \mathrm{~min}$ each to remove the excess, followed by a series of consecutive ethanol washes at concentrations of $25,50,75,95$, and $100 \%$ for 15 min each (based on $96 \%$ of ethanol). After ethanol washing, samples were washed with propylene oxide (Aldrich Chemistry), twice for $15 \mathrm{~min}$ each to remove ethanol; then, tissues were placed one hour in a 50:50 mixture of propylene oxide with the LX-112 (Ladd Research) resin. Finally, samples were placed in an Eppendorf tube to give orientation and we place LX-112 resin with a catalyst for resin polymerization. Samples were placed in an oven at $60^{\circ} \mathrm{C}$ for $48 \mathrm{~h}$. During preparation, in the step of ethanol washes, a $20 \mu \mathrm{L}$ sample was taken and deposited on a copper grid with the carbon cover and allowed to dry for observation by SEM. Once in the solid state, the resin was taken to an ultramicrotome, where ultrafine cuts $(90 \mathrm{~nm})$ were made with a diamond blade and collected with a copper grid with carbon coating to be observed by TEM. Shrimp and Vibrio parahaemolyticus cut were observed in different models of the transmission and scanning electron microscope.

2.8. Determination of Minimum Inhibitory Concentration (MIC) by a Broth Microdilution Method. For this study, a pathogenic strain from $V$. parahaemolyticus bacterium, donated by the Center for Biological Research of the Northwest (CIBNOR) [38] and characterized in the Interdisciplinary Research Center Regional Integral Development (CIIDIR) [39], was used. For growth kinetics tests, a Synergy HTX (BioTek Instruments) plate reader was used. The absorbance was monitored at $540 \mathrm{~nm}$ every $15 \mathrm{~min}$ with shaking at $30^{\circ} \mathrm{C}$ for $24 \mathrm{~h}$. Tests were carried out in new and sterile 96-well plates. Each well contained $50 \mu \mathrm{L}$ of Mueller-Hinton culture medium (Difco), $30 \mu \mathrm{L}$ of inhibitory agents $(5,10,15,20,25,30$, and $35 \mu \mathrm{g} / \mathrm{mL}$ of AgNPs and 88, 100, 110, and $330 \mu \mathrm{g} / \mathrm{mL}$ of $\mathrm{Rh}$ extract), and $20 \mu \mathrm{L}$ of inoculum of $V$. parahaemolyticus at a well concentration of $10^{5}$ cells $/ \mathrm{mL}$. Each treatment was performed in triplicate. As a blank, culture medium was used and, as a control, the bacteria without treatment. The MIC value was taken at the lowest concentration of antibacterial agents that inhibits the growth of bacteria [40].

2.9. Time-Kill Curves. An inoculum of V. parahaemolyticus was seeded on a plate with marine agar (BD Difco) at $30^{\circ} \mathrm{C}$ for $24 \mathrm{~h}$. Later, bacterial concentration was adjusted to $10^{8}$ by the McFarland method [41]. Distilled and sterilized water was used, and saline solution was prepared at $2.5 \% \mathrm{NaCl}$ (Sigma-Aldrich). For the broth macrodilution test, 5 vials were used, which contained $1 \mathrm{~mL}$ of an inhibitory agent, $500 \mu \mathrm{L}$ of $V$. parahaemolyticus inoculum, and $3.5 \mathrm{~mL}$ of Mueller-Hinton broth at $2.5 \% \mathrm{NaCl}$. In control, the volume of an inhibitory agent was replaced by culture broth. As inhibitors, AgNPs (25 and $200 \mu \mathrm{g} / \mathrm{mL}$ ) and the Rh extract $(220$ and $880 \mu \mathrm{g} / \mathrm{mL})$ were evaluated. The tested concentrations correspond to 1 and 4 times the MIC for both treatments. As a control, V. parahaemolyticus was used without treatment. During the trial, vials were maintained in constant agitation on a test tube rocker (United Products \& Instruments Inc.) at 25 cycles per minute in order to ensure contact between inhibitors and bacteria. V. parahaemolyticus initial concentration in the vials was $10^{5} \mathrm{CFU} / \mathrm{mL}$. To construct time-kill curves, samples were taken from the vials at 0,4 , 8,12 , and $24 \mathrm{~h}$. Serial ten-fold dilutions $\left(10^{-1}-10^{-8}\right)$ of the bacterial suspension had been performed in saline water (35 ppm), and $100 \mu \mathrm{L}$ was inoculated into plate count agar (PCA) $(n=3)$. After $24 \mathrm{~h}$ of incubation at $30^{\circ} \mathrm{C}, \mathrm{CFU}$ were counted and the limits of count detection were of 5$50 \mathrm{CFU}$. Killing rate was determined by plotting the total number of viable cells as $\log 10 \mathrm{CFU} / \mathrm{mL}$ versus time. Bactericidal activities have been defined as to $3-\log _{10}$ decrease in $\mathrm{CFU} / \mathrm{mL}$ (99.9\% kill) [42]. 
2.10. Reactive Oxygen Species Assays. A suspension of V. parahaemolyticus bacteria was prepared from an inoculum, and saline water $(35 \mathrm{ppm})$ was used to adjust optical density of suspension in 0.5 , measured in a spectrophotometer. Suspension was diluted to get a final concentration of $10^{5}$ bacteria per well. Bacteria were seeded in 96-well plates, where NP treatment $(25$ and $100 \mu \mathrm{g} / \mathrm{mL})$ and $\mathrm{Rh}$ extract $(220$ and $800 \mu \mathrm{g} / \mathrm{mL}$ ) were added. Treatments were incubated at $6 \mathrm{~h}$. Later, DCFDA $\left(2^{\prime}, 7^{\prime}\right.$-dichlorofluorescin diacetate $)$ was added at a concentration of $10 \mu \mathrm{M}$ (Sigma), which was incubated for $2 \mathrm{~h}$ and subsequently analyzed in a spectrofluorometer Synergy HTX (BioTek) at an excitation and emission wavelength of $485 / 528 \mathrm{~nm}$.

2.11. A. franciscana Nauplii and Toxicity Test. In the present work, A. franciscana nauplii from INVE brand cysts were used as a vector for AgNPs and Rh extract in the treatment of shrimp postlarvae infected with $V$. parahaemolyticus. For hatching, $0.5 \mathrm{~g}$ of $A$. franciscana cysts was weighed in a flask with constant aeration and illumination with a white light led lamp ( $20 \mathrm{~W})$, containing $500 \mathrm{~mL}$ of diluted seawater at $35 \mathrm{ppt}$ (part per thousand), previously filtered with $0.2 \mu \mathrm{m}$ acrodisc filter and sterilized in an autoclave, at a temperature of $30^{\circ} \mathrm{C}$ for $48 \mathrm{~h}$. Nauplii were harvested and washed three times with sterile seawater to reduce their bacterial load and resuspended again in sterile seawater in a clean flask. Before experimental use, the density of nauplii was estimated in the container. Johari et al. have proposed the use of a standardized method to evaluate the toxicity of nanoparticles in Artemia nauplii with a ISO/TS 20787 based mainly on behavior of specimens and proposing a positive control with potassium dichromate [43].

For the toxicity test, an average of $25 \mathrm{~A}$. franciscana nauplii were placed per well in a six-well culture plate $(10 \mathrm{~mL}$ each well). Each well contained $4.5 \mathrm{~mL}$ of seawater, $1 \mathrm{~mL}$ of aliquot of $A$. franciscana nauplii stock, and $0.5 \mathrm{~mL}$ of treatment, for a total volume of $6 \mathrm{~mL}$ per well and concentrations of 45 and $50 \mu \mathrm{g} / \mathrm{mL}$ of NPs and 220 and $240 \mu \mathrm{g} / \mathrm{mL}$ of $\mathrm{Rh}$ extract. Each treatment was performed in triplicate. A. franciscana nauplii were observed and counted every six hours through a stereoscope during $24 \mathrm{~h}$. At the end of the assay, the number of active (live) nauplii was recorded and survival percentage was calculated for each well and separate experiments using following equation:

$$
\text { \%survival }=\frac{\# \text { live nauplii }(t)}{\text { \#live nauplii }\left(t_{0}\right)} \times 100 .
$$

2.12. L. vannamei Postlarvae Survival Assay. White shrimp postlarvae in stage $\mathrm{Pl}-15$ (fifteen days in a postlarval stage) were obtained from GENITECH S.A. (San Agustin, Sonora, Mexico). The shrimp postlarvae in the mentioned stage were deposited in our laboratory in a plastic container of $250 \mathrm{~L}$ with saline water at $30^{\circ} \mathrm{C}$. The organisms remained for 5 days with air flux and commercial feed until the survival assay. Correspondingly, A. franciscana cysts were hatched according to the protocol described above. The newly hatched nauplii were divided in petri dishes with a total volume of $10 \mathrm{~mL}$ for later treatment $(50 \mu \mathrm{g} / \mathrm{mL}$ of AgNPs and $220 \mu \mathrm{g} / \mathrm{mL}$ of Rh extract), for $18 \mathrm{~h}$. Prior to the survival assay, two groups with $300 \mathrm{Pl}-20$ were placed in two $500 \mathrm{~mL}$ beakers, with $250 \mathrm{~mL}$ of seawater. For each shrimp postlarvae, $50 \mathrm{~A}$. franciscana nauplii were placed, "loaded" with different agents on each beaker, and the Pl-20 were fed with them for $4 \mathrm{~h}$. Nine fed postlarvae were chosen randomly for each treatment and then verted into flasks with $300 \mathrm{~mL}$ of seawater, with an aeration and at $30^{\circ} \mathrm{C}$. Assays were realized by triplicate, so a total of 27 postlarvae were counted by treatment. For toxicity assay, 3 groups were obtained (G-1: shrimps fed with untreated $A$. franciscana and noninfected, G-2: shrimps fed with AgNPs-A. franciscana-and noninfected, and G-3: shrimps fed with $\mathrm{Rh}-A$. franciscana-and noninfected). For the microbial challenge, inoculum of $V$. parahaemolyticus was aggregated on corresponding flasks with fed postlarvae to get a concentration of $10^{5}$ cells $/ \mathrm{mL}$. After four hours of infection, it was considered the initial time of survival monitoring $(t=0 \mathrm{~h})$. Finally, 6 groups were obtained: G-4: shrimps fed with untreated $A$. franciscana and infected, G-5: shrimps fed with AgNPs-A. franciscana-and infected, and G-6: shrimps fed with $\mathrm{Rh}-A$. franciscana-and infected. During the experiment, live organisms were counted every six hours during $24 \mathrm{~h}$. At the end, samples were harvested and fixed in $4 \%$ glutaraldehyde for later observation by SEM. Statistical analysis was performed using 2-way ANOVA with the Origin software followed by Tukey HSD; significant differences are expressed $(P<0.05)$.

\section{Results and Discussion}

3.1. UV-Vis and IR Spectroscopy. El-Shahaby et al. [44] reported AgNP synthesis using Rumex dentatus (R. dentatus) extracts, where they obtain sizes between 5 and $30 \mathrm{~nm}$, and the maximum absorption band associated with AgNPs is located at $460 \mathrm{~nm}$. In our synthesis, we have maximum absorption band at $415 \mathrm{~nm}$ (Figure 1(a)), which confirms that our NPs show smaller sizes $(2-10 \mathrm{~nm})$. These results may be due to the types of compounds present in the respective extracts. Since in the case of $\mathrm{Rh}$, whose extracts are obtained from the plant root, the main antioxidant molecules are catechins (EC, ECG, and EGCG) and stilbenes (t-resveratrol glycoside) [20]. While in $R$. dentatus, the extract used comes from the aerial part of the plant, where phenolic compounds stand out and hydroxyl groups, potentially reducing, are not as abundant as in the case of catechins.

AgNPs synthesized with Rh extract have the appropriate sizes to achieve a remarkable bactericidal effect, which is smaller than $15 \mathrm{~nm}$, according to other authors [45, 46]. It has recently been shown that AgNPs obtained with $\mathrm{Rh}$ extracts have inhibitory effects on gram-positive and gramnegative bacteria [21]; in addition, it has been demonstrated that NPs form a composite NP-Rh extract system. Results described above support UV-Vis and IR spectroscopy data, where the NP system, even after undergoing a cleaning process, signals corresponding to the extract that can be detected. Remarkably, we can establish that NPs are complexed to Rh extract, which favors the system stability by forming a AgNP-Rh extract complex, which may improve the bactericidal activity. 


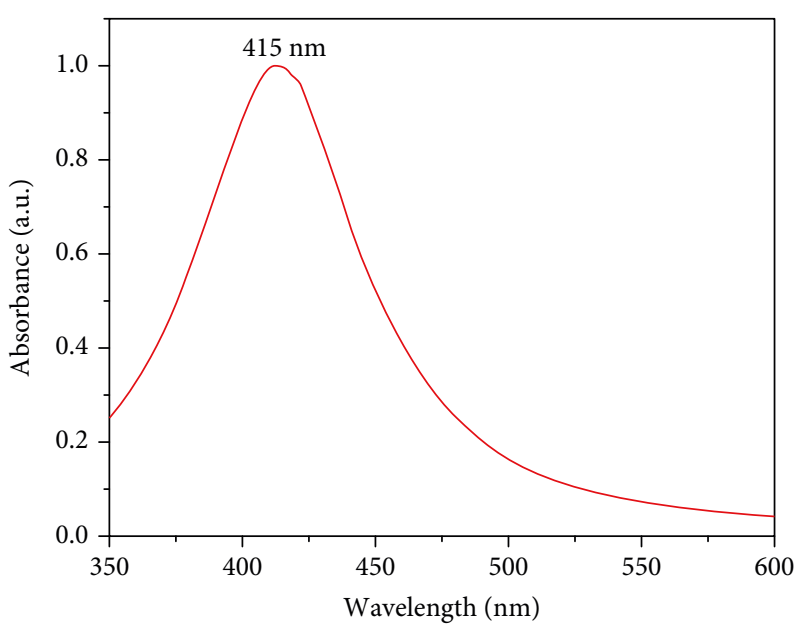

(a)

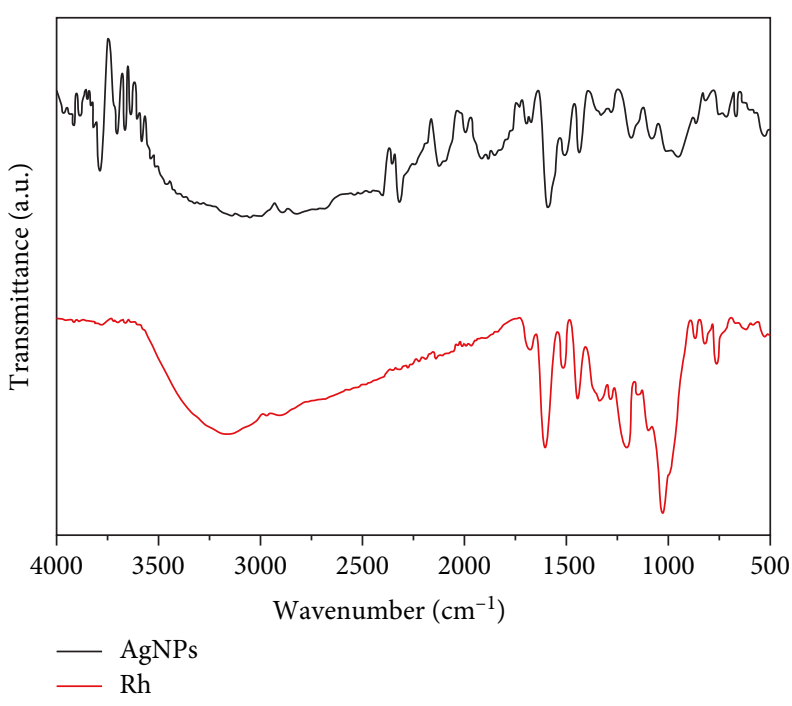

(b)

FIgURE 1: (a) UV-Vis spectrum of AgNPs synthesized with Rh extract under sunlight illumination. (b) FTIR spectrum of Rh extract and AgNPs.

TABLE 1: $\zeta$, size, and $\sigma$ analysis of AgNPs at different concentrations. All measurements show standard deviation (SD), and size also shows a polydispersity index (PDI).

\begin{tabular}{lcccc}
\hline Concentration $(\mu \mathrm{g} / \mathrm{mL})$ & $\zeta(\mathrm{mV})$ & Size $(\mathrm{nm})$ & PDI & $\sigma(\mathrm{mS} / \mathrm{cm})$ \\
\hline 6.25 & $-46.3 \pm 0.95$ & $82.75 \pm 0.25$ & $0.556 \pm 0.03$ & $0.123 \pm 0.003$ \\
12.5 & $-47.1 \pm 0.40$ & $79.86 \pm 0.18$ & $0.552 \pm 0.005$ & $0.0156 \pm 0.005$ \\
25 & $-49 \pm 1.36$ & $80.91 \pm 0.36$ & $0.56 \pm 0.006$ & $0.0117 \pm 5.77 \times 10^{-5}$ \\
50 & $-48.3 \pm 1.1$ & $80.61 \pm 0.03$ & $0.554 \pm 0.003$ & $0.0176 \pm 0.008$ \\
100 & $-47.9 \pm 0.40$ & $79.97 \pm 0.43$ & $0.55 \pm 0.006$ & $0.0189 \pm 3.179 \times 10^{-4}$ \\
\hline
\end{tabular}

In the FTIR spectrum of AgNPs (Figure 1(b)), the peak centered around $1650 \mathrm{~cm}^{-1}$ is more intense than in $\mathrm{Rh}$ extract, which could be the carbonyl group $(\mathrm{C}=\mathrm{O})$ between 1620 and $1690 \mathrm{~cm}^{-1}[47,48]$. In such way, this increase in the signal can be attributed to the presence of quinones, generated by polyphenolic molecule oxidation present in Rh extract. These data confirm that NPs are stabilized by polyphenolic molecules. AgNPs have been subjected to a cleaning protocol to remove extract excess.

3.2. Size, Zeta Potential, and Conductivity. Size measurements by DLS (Zetasizer NS) show that the mean hydrodynamic radio of AgNPs is $80.82 \pm 1.1642 \mathrm{~nm}$, which does not change as concentration increases (Table 1). AgNP $\zeta$ was measured to 5 different concentrations in a range of $6.25-100 \mu \mathrm{g} / \mathrm{mL}$. Table 1 shows the $\zeta$ values of NPs, whose mean value is $-47.72 \pm 1.0498 \mathrm{mV}$, showing high stability. Moreover, conductivity $(\sigma)$ of solutions was measured for the same range of concentrations, whose mean value was $0.01522 \pm 0.00317 \mathrm{mS} / \mathrm{cm}$ (see Table 1). All NPs were dissolved in ultrapure water. When AgNPs were dissolved in a $\mathrm{NaCl}(35 \mathrm{~g} / \mathrm{L})$ buffer, the size, $\zeta$, and $\sigma$ change drastically, data not shown. In this medium, only AgNP size was increasing in time.
3.3. Transmission and Scanning Electron Microscopy. Using TEM, stable particles of quasi-spherical geometry were observed (Figure 2(a)), where NP average size is $4.9 \pm 1.4$ $\mathrm{nm}$ with sizes between 2 and $10 \mathrm{~nm}$ (Figure 2(a) inset). In Figure 2(b), the TEM micrographs of a region of AgNPs and its corresponding selected area electron diffraction (SAED) are observed. From analysis, it was obtained that diffraction rings correspond to crystalline planes. Miller indexes are indicated, and cubic structure centered on the faces $(\mathrm{fcc})$ of Ag, according to the crystallographic sheet 04-0783 of the International Diffraction Data Center (ICDD).

Images in Figure 2(c) correspond to high-resolution HRTEM micrographs of a set of AgNPs and an individual AgNPs (Figure 2(d)). In both images, the crystalline planes, whose distances were determined by the processing of the images using the Digital Micrograph software, are clearly identifiable. In all cases, a distance $d=2.3 \AA$ was obtained; the crystallographic planes used in the determination of distance are shown in red. On Figure 2(d) inset, the image corresponding to fast Fourier transform (FFT) of the individual AgNPs is shown. It is observed that the obtained diffraction corresponds to plane (111) of Ag fcc crystal structure. 


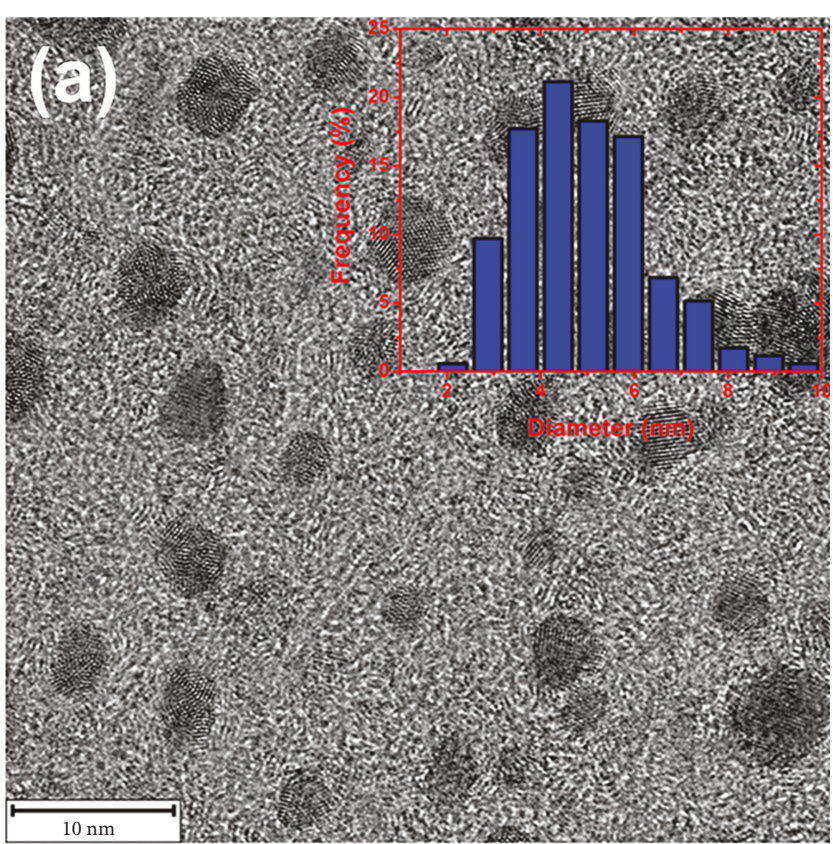

(a)

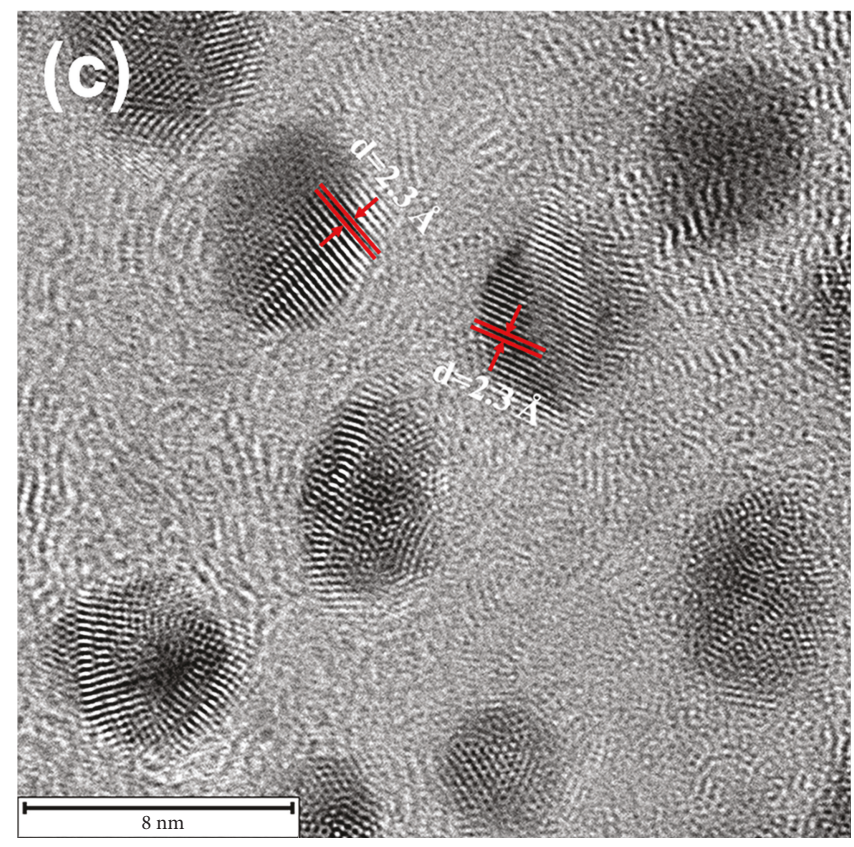

(c)

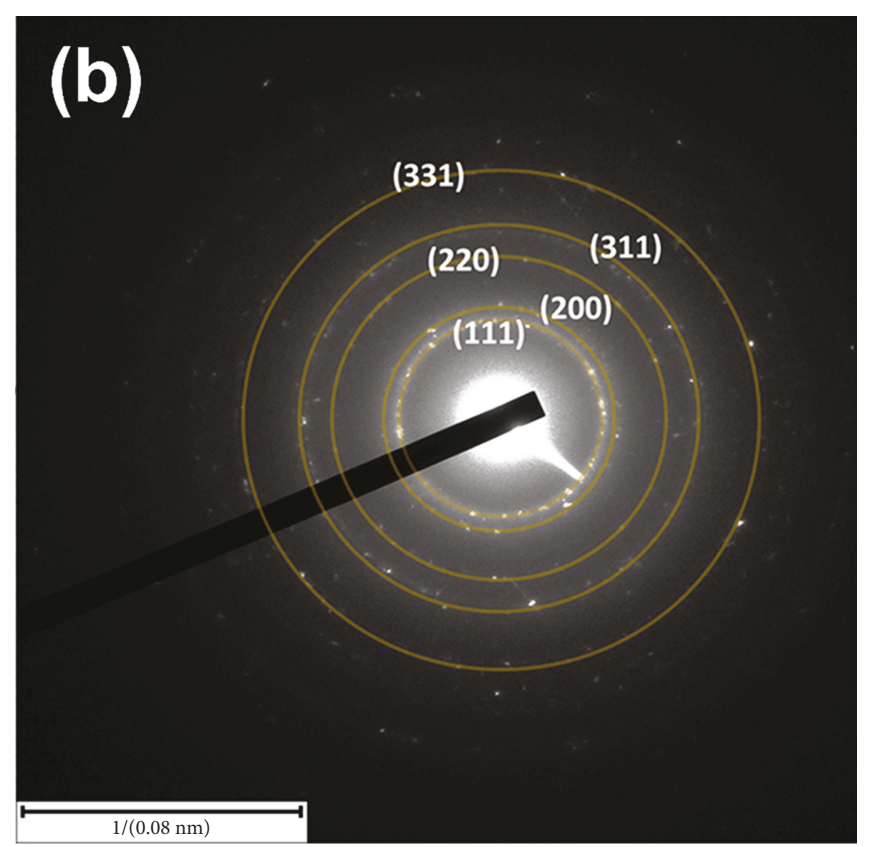

(b)

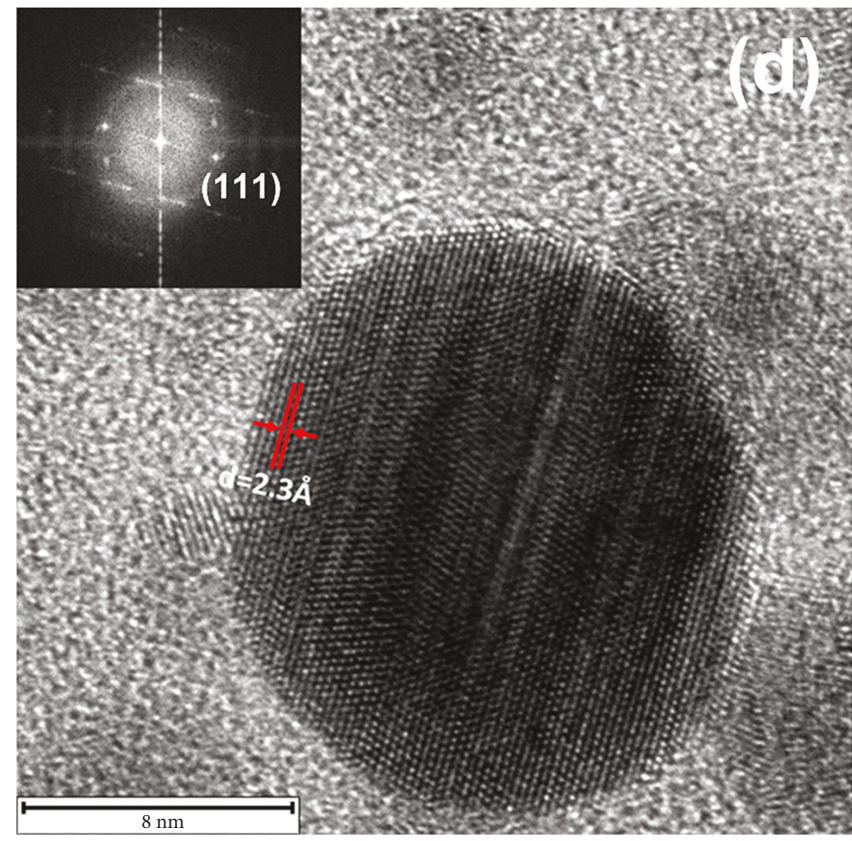

(d)

FIgURe 2: TEM micrography of AgNPs at different magnifications. (a) Panoramic field and size distribution statistic (inset), (b) SAED, and (c) and (d) HRTEM of AgNPs.

Figure 3(a) shows the micrograph SEM formed by secondary electrons (SE) of the AgNP system. It can be seen that a continuous film envelops the nanoparticles. This covering corresponds to compounds of Rh extract that stay yet, after a clean process. When depositing a sample drop of AgNPs over an electron microscopy grid, solvent evaporated and dried $\mathrm{Rh}$ extract forming the coverage shown. Figure $3(\mathrm{~b})$ shows the image formed by SEM in the transmission mode where it can be seen through extract coverage, clearly reveal- ing the presence of AgNPs. Thus, silver nanoparticles are stabilized by extract molecules adsorbed on surface forming a composite material of organic (extract) and inorganic (AgNPs) parts. This confirms results obtained by FTIR and explains why hydrodynamic radius obtained by DLS is much greater than AgNP size determined by TEM. Preliminary thermogravimetric analysis for this system that will be published soon has allowed estimating the organic content in $30 \%$ of weight. 


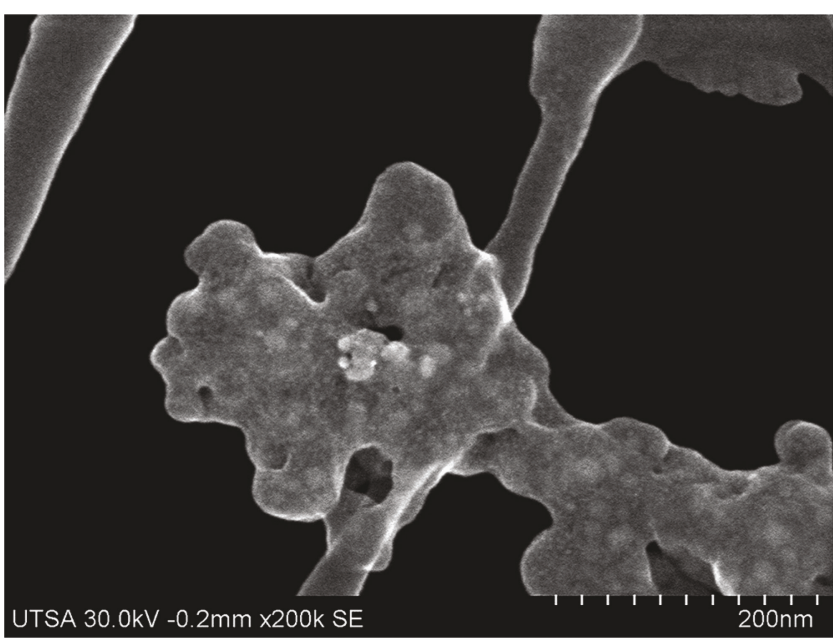

(a)

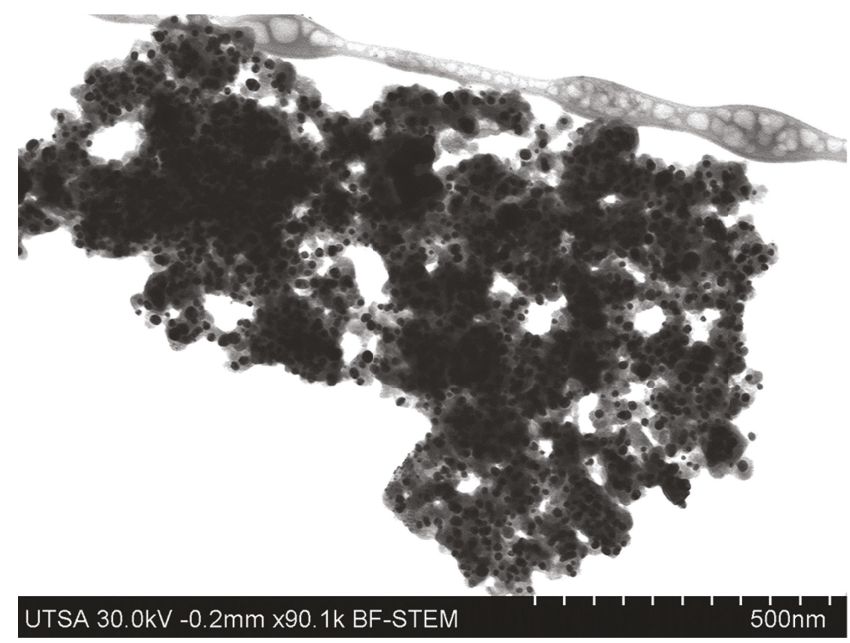

(b)

Figure 3: AgNPs by (a) SE by SEM and (b) BF transmission mode (STEM).

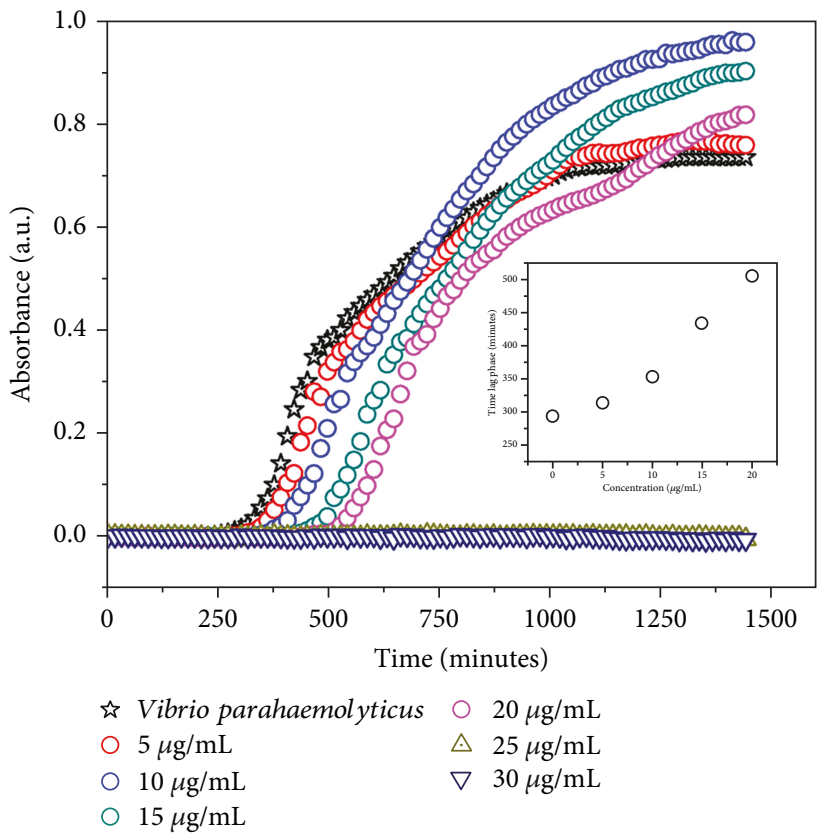

(a)

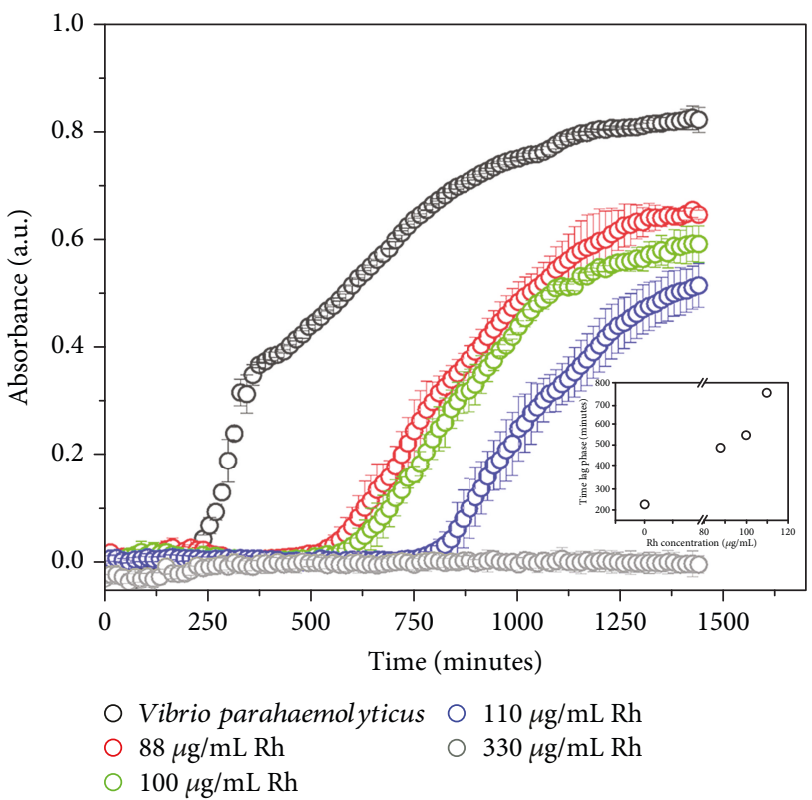

(b)

FIgURE 4: Growth kinetics for V. parahaemolyticus using (a) AgNPs and (b) Rh.

3.4. MIC Determination. When bacterial growth kinetics treated with AgNPs were analyzed, there is an effect produced by the nanomaterial. In concentrations from 5 to $20 \mu \mathrm{g} / \mathrm{mL}$, a delay in the log phase can be observed, which apparently is dependent on AgNP concentration. However, after a phase of exacerbated growth is manifested, bacterial growth is even higher than in bacteria that did not receive any treatment, as shown in Figures 3(a) and 3(b). There are reports showing that bacteria such as Escherichia coli and Pseudomonas aeruginosa have become resistant to AgNPs. This is through flagellin protein, which decreases AgNP stability, thus decreasing the bactericidal effect [49]. V. parahae- molyticus also has flagellin [50-52], and it is possible to think that effects of AgNPs at the lowest concentration are due to the mechanism mentioned above. This indicates that maybe there is an adaptation phase by $V$. parahaemolyticus to AgNPs; however, more experiments are needed to clarify the involved mechanisms.

The MIC of AgNPs and Rh extract was 25 and $220 \mu \mathrm{g} / \mathrm{mL}$, respectively, showing bacterial inhibition (Figures 4(a) and 4(b)). AgNPs were synthesized with Spirulina extract to control V. parahaemolyticus [53], tested and performed the inhibition tests by the well method. They found that concentration of NPs corresponding to 25, 50, and 


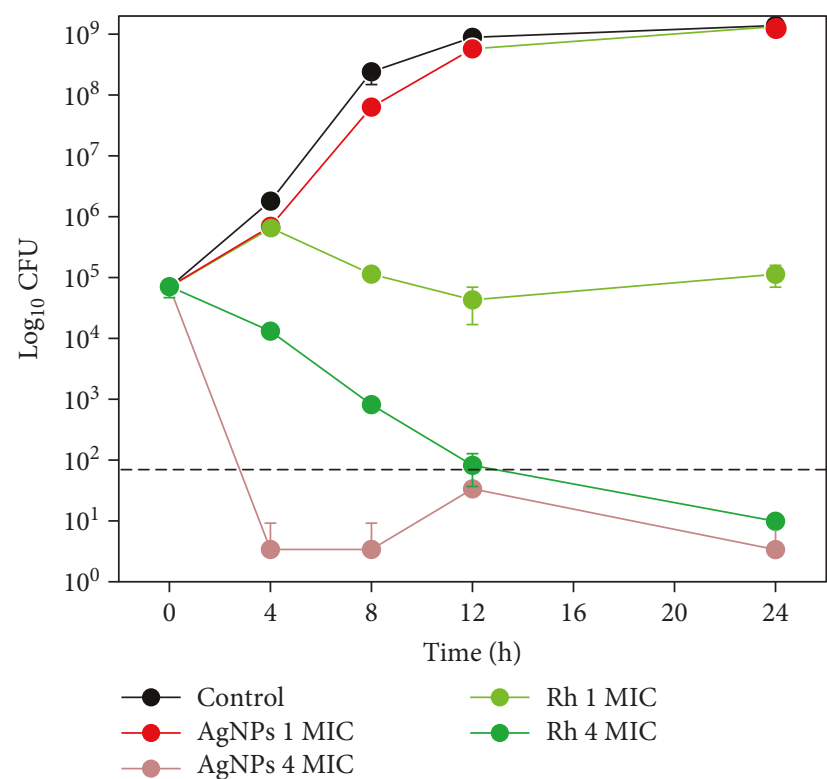

(a)

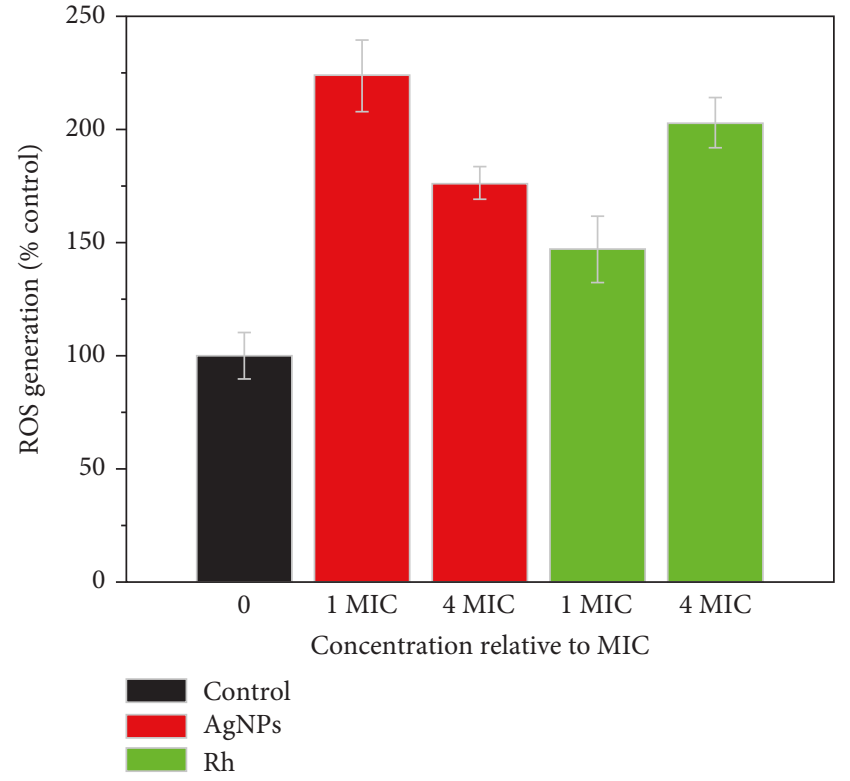

(b)

Figure 5: AgNPs and Rh in Vp for $1 \mathrm{MIC}$ and 4 MIC by (a) time-kill curves and (b) ROS generation. Dash line in (a) corresponds to microbicidal concentration.

$75 \mu \mathrm{g} / \mathrm{mL}$ presented the same halo of inhibition, without difference between them. Likewise, the extract of the Spirulina plant used to synthesize NPs showed no inhibition on $V$. parahaemolyticus.

The tested different concentrations of AgNPs against Vibrio harveyi showed that, at $35 \mu \mathrm{g} / \mathrm{mL}$, there was no growth of the bacteria [54]. This value is higher than that found in our study of $25 \mu \mathrm{g} / \mathrm{mL}$. Johari et al. discuss that heavy metals react with proteins by combining the - $\mathrm{SH}$ groups of enzymes, which leads to the inactivation of proteins $[55,56]$; they use a powdered silver zeolite (SZ) to evaluate the Saprolegnia growth in different concentrations of SZ.

The molecular mechanism of action on the effect caused by EGCG on bacterial inhibition is not yet well understood. On the one hand, some authors suggest that the hydrogen peroxide, produced by EGCG on an alkaline environment, shows up a mechanism to be related with bacterial inhibition [57-59]. On the other hand, Xiong et al. [60] suggest that bactericidal action of EGCG is because of a considerable increase in intracellular oxidative stress, due the coadministration of antioxidant. Moreover, it has been proposed that deposits of EGCG on the outer membrane of gram-negative bacteria block the porin protein channel inhibiting their function [61]. Resveratrol properties have also been studied in bacteria. It has been reported that in gram-negative bacteria such as E. coli, resveratrol affects bacterial metabolic activity, where it has been observed that it inhibits ATP synthase, which affects both hydrolysis and synthesis of ATP. Resveratrol also induces DNA fragmentation and abnormal cell division due to the inhibition of FtsZ protein, resulting in bacterial cells with elongated structure $[62,63]$. In other studies, it has been reported that the MIC for V. cholera is $60 \mu \mathrm{g} / \mathrm{mL}$ using resveratrol. As mentioned above, in this work, the MIC for $V$. parahaemolyticus was $25 \mu \mathrm{g} / \mathrm{mL}$, a concentration lower than that reported for $V$. cholera; however, it must be considered that resveratrol concentration in the nanocomposite may be lower, since the organic part is composed of a pool of compounds, such as EGCG and resveratrol.

3.5. Time-Kill Curves and Reactive Oxygen Species Assays. Time-kill curves for AgNPs and Rh are shown in Figure 5(a). AgNPs have a bactericidal effect at 4 times MIC concentration $(100 \mu \mathrm{g} / \mathrm{mL})$, where a clear effect is observed at four hours. For AgNPs in the concentration of $1 \mathrm{MIC}(25 \mu \mathrm{g} / \mathrm{mL})$, it is observed that the growth phase is delayed, which is recovered at $24 \mathrm{~h}$, even reaching the control level. For Rh extract, it is found that for the concentration of 4 times the MIC $(880 \mu \mathrm{g} / \mathrm{mL})$ the bactericidal effect is reached after $12 \mathrm{~h}$, whereas for the concentration of $1 \mathrm{MIC}$ $(220 \mu \mathrm{g} / \mathrm{mL})$ only a bacteriostatic effect is observed.

In order to elucidate the mechanisms by which AgNPs and Rh extract exert a bactericidal effect, ROS production assays were carried out (Figure 5(b)). When analyzing ROS production of AgNPs at concentration of $1 \mathrm{MIC}$, it was found that there is a significant production of ROS. If the obtained result is compared with the concentration of 4 times the MIC, it is possible to notice that ROS production is lower; however, this may be due to a lower concentration of bacteria as shown in the time-kill curves, which translates into a lower ROS production. AgNPs bactericidal effect at 4 times the MIC concentration can be due to a synergistic effect of membrane damage by AgNPs coupled to ROS production by the particles that may be internalized [64]. In the case of Rh extract, it is observed that ROS production increases as the extract concentration increases, which leads us to think that the death mechanism produced by the extract is by ROS, which 


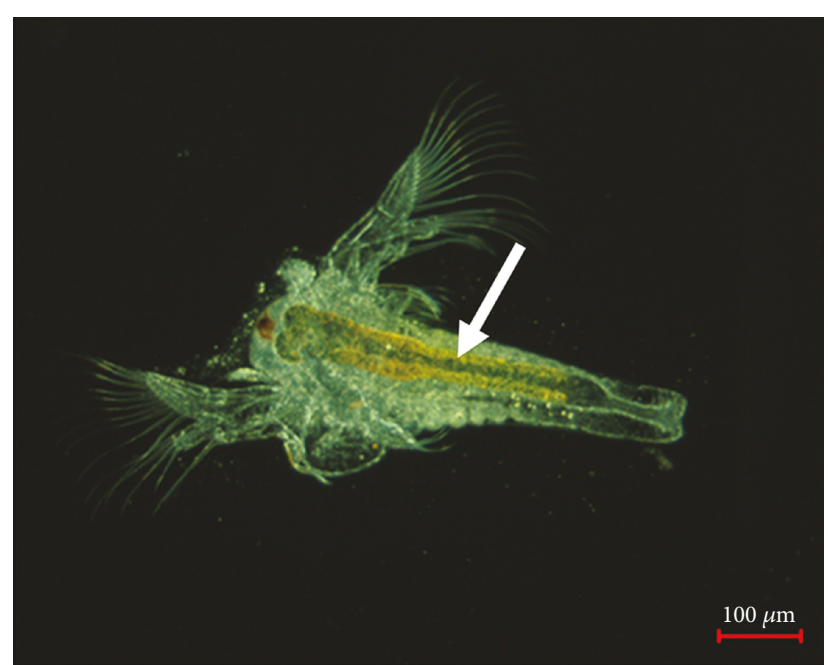

(a)

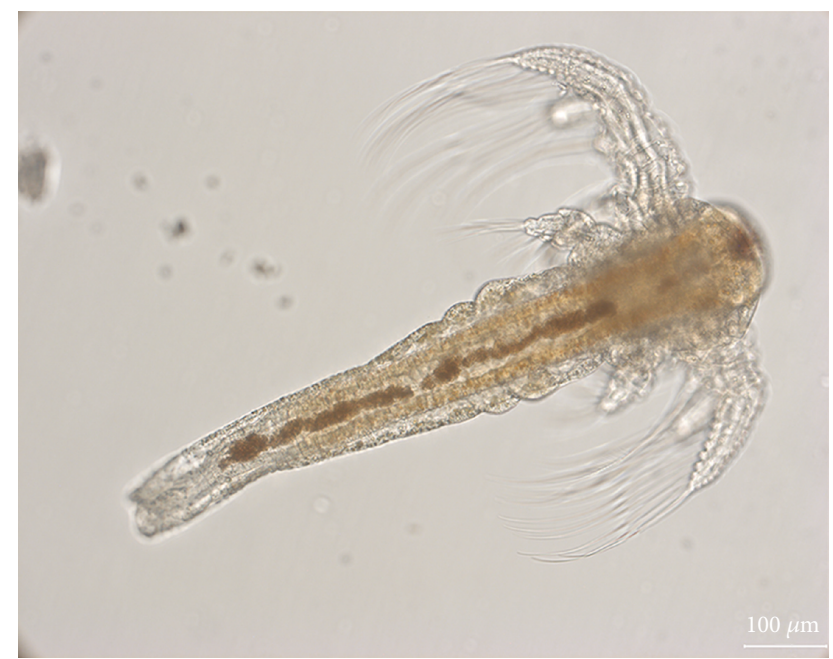

(c)

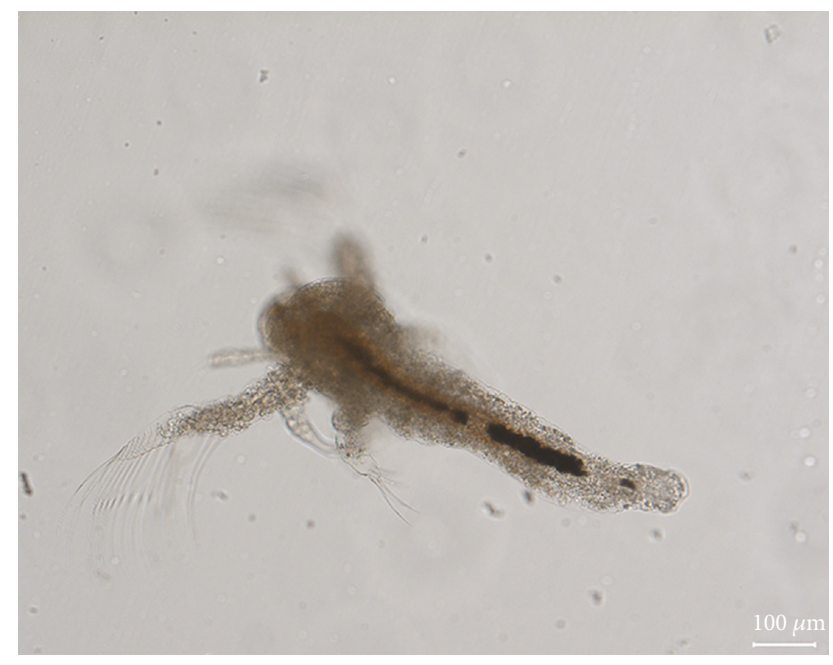

(e)

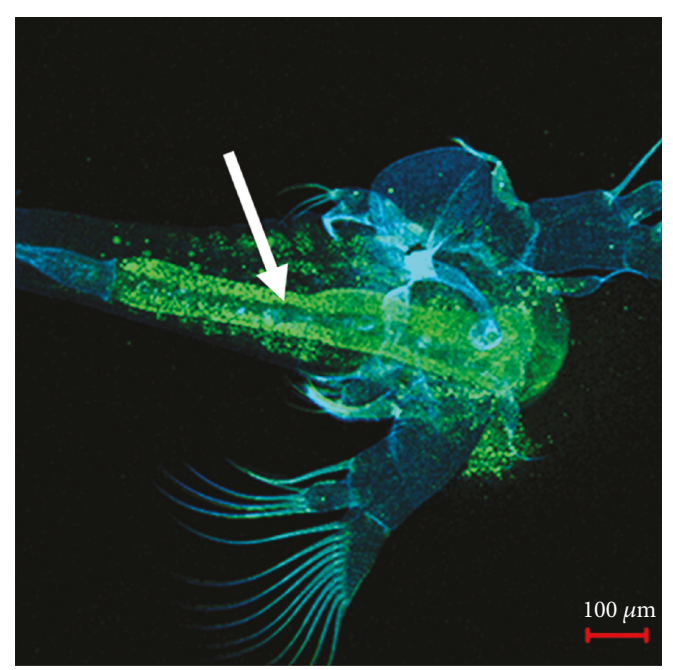

(b)

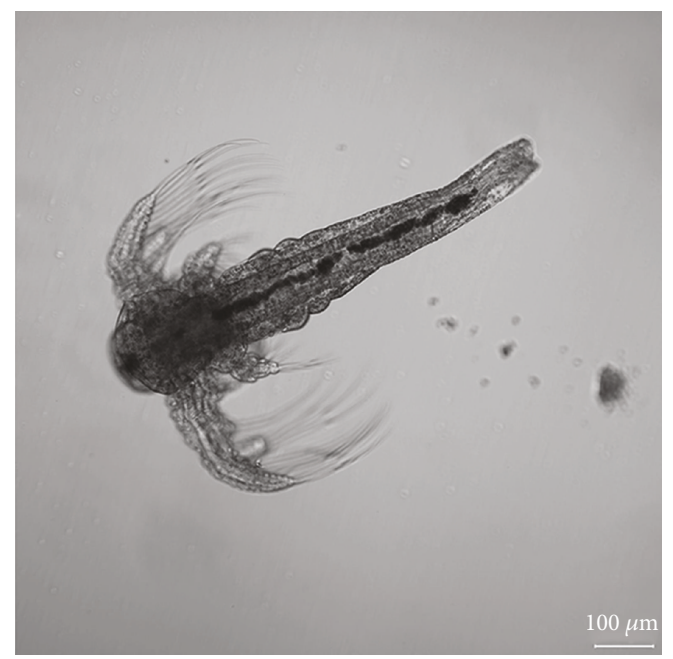

(d)

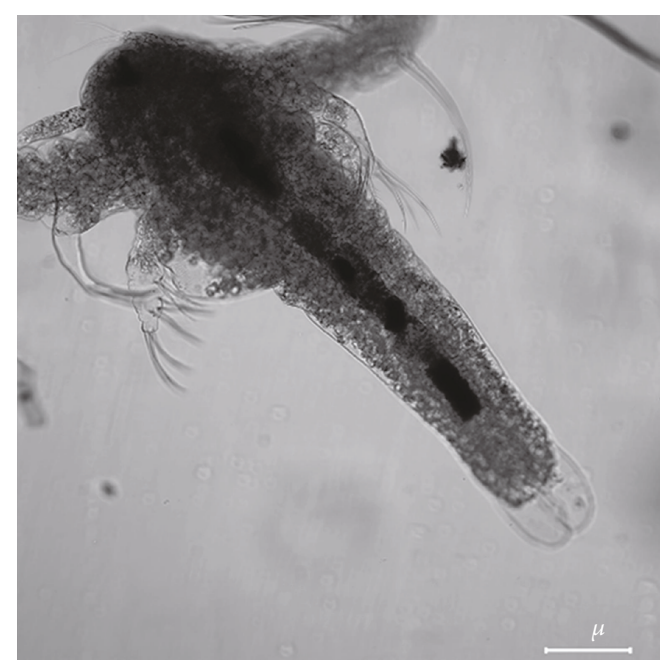

(f)

Figure 6: (a) Dark field microscopy of A. franciscana, $24 \mathrm{~h}$ after hatching without treatment, and (b) confocal laser scanning microscopy Artemia autofluorescence. Artemias $24 \mathrm{~h}$ after treatment with $\mathrm{Rh}$ extract (c, d) and AgNPs (e, f), images obtained by white light microscopy (e) and CLSM (f). 
TABLE 2: Survival assay percentage of Artemia nauplii exposed at different concentrations of AgNPs and Rh extract.

\begin{tabular}{lccccc}
\hline Time $(\mathrm{h})$ & Control & AgNPs $(45 \mu \mathrm{g} / \mathrm{mL})$ & AgNPs $(50 \mu \mathrm{g} / \mathrm{mL})$ & $\mathrm{Rh}(220 \mu \mathrm{g} / \mathrm{mL})$ & $\mathrm{Rh}(240 \mu \mathrm{g} / \mathrm{mL})$ \\
\hline 0 & 100 & $100 \pm 0$ & $100 \pm 0$ & $100 \pm 0$ & $100 \pm 0$ \\
6 & 100 & $89.7 \pm 2.2$ & $97.1 \pm 2.5$ & $100 \pm 0$ & $100 \pm 0$ \\
12 & 100 & $88.4 \pm 0.4$ & $93 \pm 2.7$ & $98.6 \pm 2.3$ & $98.76 \pm 2.1$ \\
18 & 100 & $88.4 \pm 0.4$ & $91.4 \pm 2.2$ & $97.3 \pm 4.6$ & $98.7 \pm 2.1$ \\
24 & 100 & $88.4 \pm 0.4$ & $91.4 \pm 2.2$ & & $97.5 \pm 4.2$ \\
\hline
\end{tabular}

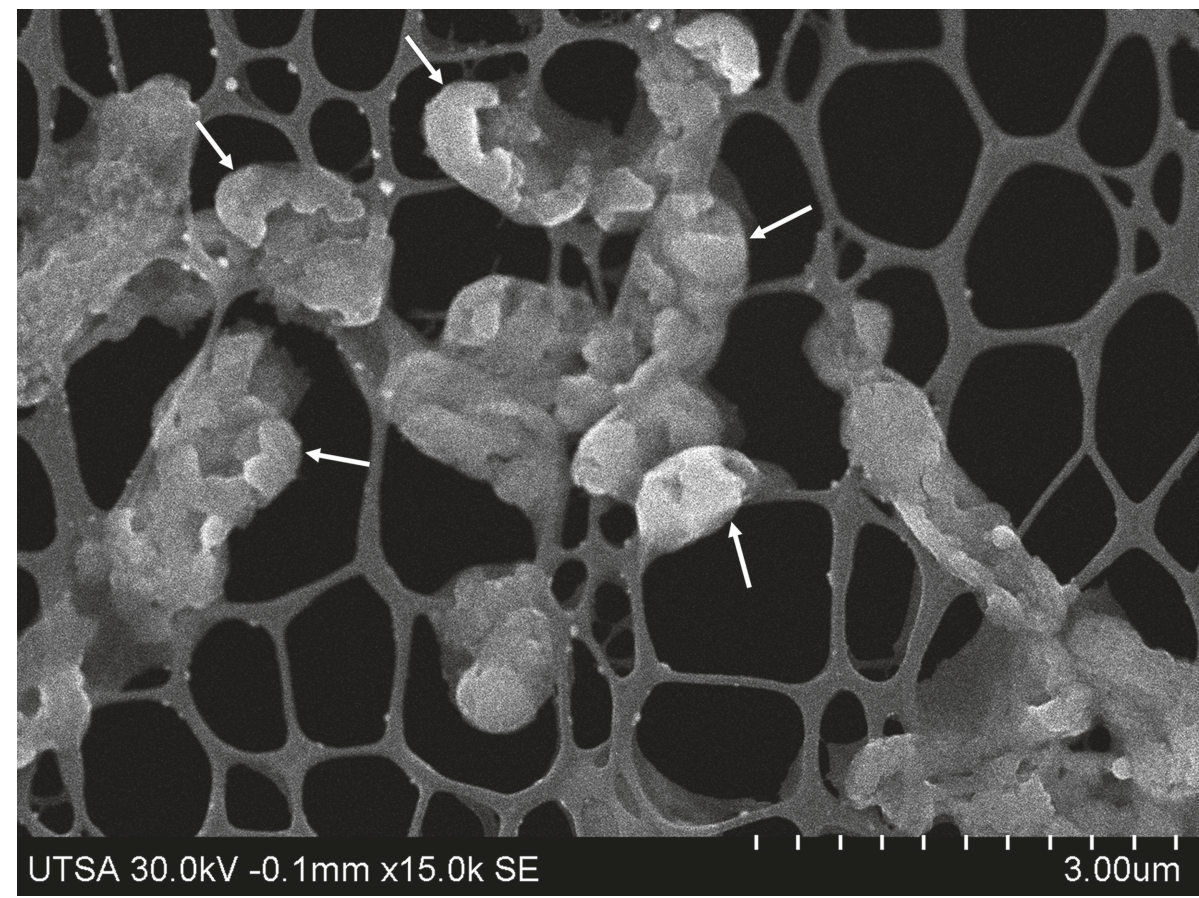

Figure 7: Scanning electron micrograph of V. parahaemolyticus exposed at AgNPs. The arrows point to the bacteria destroyed.

it is known to be induced by EGCG, a compound found in the extract.

The results obtained by time-kill curves for AgNPs differ from the results obtained in MIC determination assays, where, at $25 \mu \mathrm{g} / \mathrm{mL}$, it is found that there is no bacterial growth. Several works on microbicidal activity of silver nanoparticles report MBC values lower than $10 \mu \mathrm{g} / \mathrm{mL}$; however, time-kill curves are performed in small volumes, which could affect the material/bacteria interaction $[65,66]$.

3.6. Survival Assay for Artemia. Concentrations of AgNPs ( 45 and $50 \mu \mathrm{g} / \mathrm{mL})$ and $\mathrm{Rh}(220$ and $240 \mu \mathrm{g} / \mathrm{mL})$, which showed the highest inhibitory activity against $V$. parahaemolyticus, were evaluated in Artemia nauplii. Figure 6(a) shows the hatched and unfed brine shrimp. Figure 6(b) corresponds to the autofluorescence of Artemia obtained by confocal microscopy. In both images, the arrows indicate the digestive tract of the brine shrimp without feed and perfectly clean. At $18 \mathrm{~h}$ after fed Artemia, most of the organisms presented material in the intestine, Rh extract (Figures 6(c) and 6(d)) and AgNPs (Figures 6(e) and 6(f)). The survival before both concentrations of AgNPs was slightly higher than 88\%. There were no differences for both concentrations, with a survival higher than 95\% (Table 2). No significant differences were found between the two treatments $(P<0.05)$.

In the literature reviewed, there were no records of the use of Artemia nauplii as a NP vector; however, there are works where it has been used as a model to evaluate the toxicity of nanomaterials. Wang et al. [67] evaluated the toxicity of $\alpha-\mathrm{Fe}_{2} \mathrm{O}_{3}$ NPs in A. salina. They reported mortalities of $20 \%$ at a concentration of $50 \mathrm{mg} / \mathrm{L}$, like those found in our work with $10 \%$ mortality at $24 \mathrm{~h}$ of the Artemia toxicity test at $50 \mu \mathrm{g} / \mathrm{mL}$. The toxicity and effectiveness of AgNPs synthesized with Adhatoda vasica were evaluated, testing Artemia against $V$. parahaemolyticus bacteria [6]; the authors reported that in their results at $24 \mathrm{~h}$ in the case of NPs ( $50 \mathrm{mg} / \mathrm{mL}$ ) showed survival below $75 \%$ in Artemia.

3.7. V. parahaemolyticus Samples Prepared for Ultramicrotomy Observation by TEM and SEM. With the purpose of visualizing possible structural damage due to AgNPs on V. parahaemolyticus, an inoculum of the bacteria 


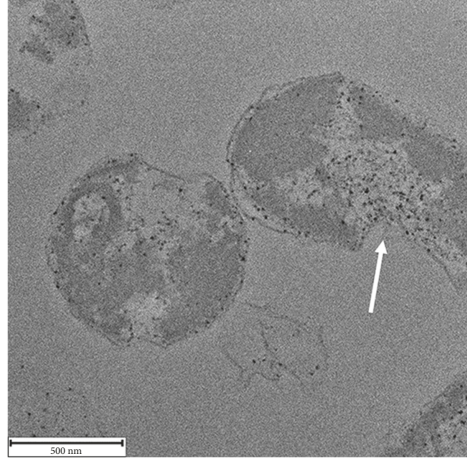

(a)

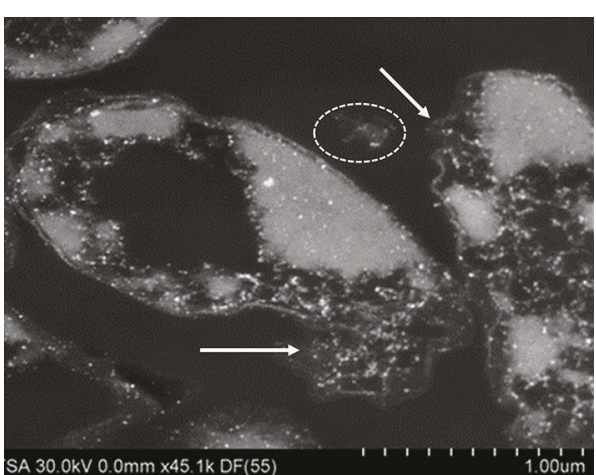

(b)

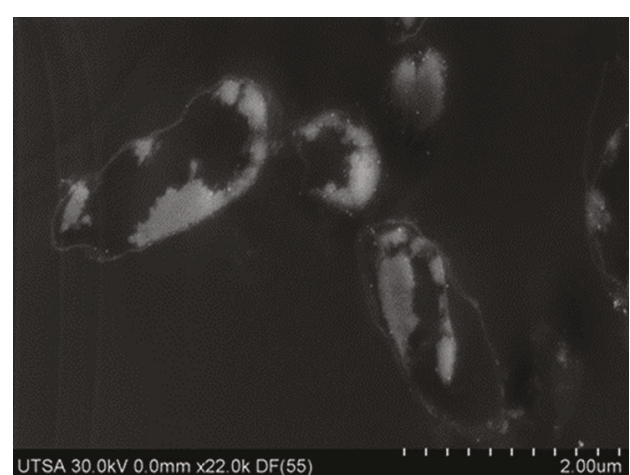

(c)

FIgURE 8: V. parahaemolyticus exposed at AgNPs: TEM micrograph (a) and SEM (dark field) micrograph (b). V. parahaemolyticus without treatment, SEM micrograph (c). Images correspond at samples prepared by ultramicrotome. The arrows indicate regions where bacteria membrane shows damage.

was exposed to a high concentration of NPs $(100 \mu \mathrm{g} / \mathrm{mL})$ for $24 \mathrm{~h}$. Subsequently, it was fixed in glutaraldehyde for its preparation and observation by electron microscopy. Figure 7 corresponds to the SEM micrograph of $V$. parahaemolyticus exposed to AgNPs. The structural damage to the bacteria is clear, as indicated by the arrows. To track the location of AgNPs in the bacteria, samples were processed by ultramicrotomy. Figures 8 (a) and 8 (b) correspond to micrographs of $V$. parahaemolyticus with AgNPs obtained by TEM and SEM (dark field), respectively. Arrows indicate the areas where the plasma membrane is discontinuous, probably because of AgNPs internalized in the bacteria (black dots in (a) and bright spots in (b)). Figure 8(c) corresponds to the SEM (dark field) micrograph of $V$. parahaemolyticus without AgNPs. It is observed that bacterial membranes are found undamaged, which coincides with the absence of bright spots (AgNPs). Radhakrishnan et al. used ultramicrotome bacterial cells treated with AgNPs (1/5 MIC) in TEM micrographs to show that damage to the cell membrane led to leakage of the cytoplasm [68]. Hartmann et al. indicate the damage to the integrity of the cell wall after treatment with AgNPs [69], as observed in Figure 8(a). Siritongsuk et al. studied the damage in $E$. coli bacteria observed by TEM and show that cells contain additional membranous structures [42]; in Figure 8(b), we observe these additional structures. Yin et al. have described using SEM AgNPs located on the cytoplasmic membrane and cell wall [70], similar results we observed in Figure 8(b).

3.8. Shrimp Survival Assays. In the control treatment, where AgNPs and Rh extract were used, as well as postlarvae without inhibitory elements, all without infection, 100\% survival was obtained, with the exception of the control, which presented a shrimp survival of approximately 95\%. No significant difference was found between treatments $(P<0.05)$. With respect to treatments and after $24 \mathrm{~h}$ of experimentation, survival was recorded for the treatments: for Rh extract 92.1\%, for AgNPs 87.5\%, and for control 58.3\%. No statistical differences were found between NP and Rh treatments but yes between Rh and control treatments (Figure 9).

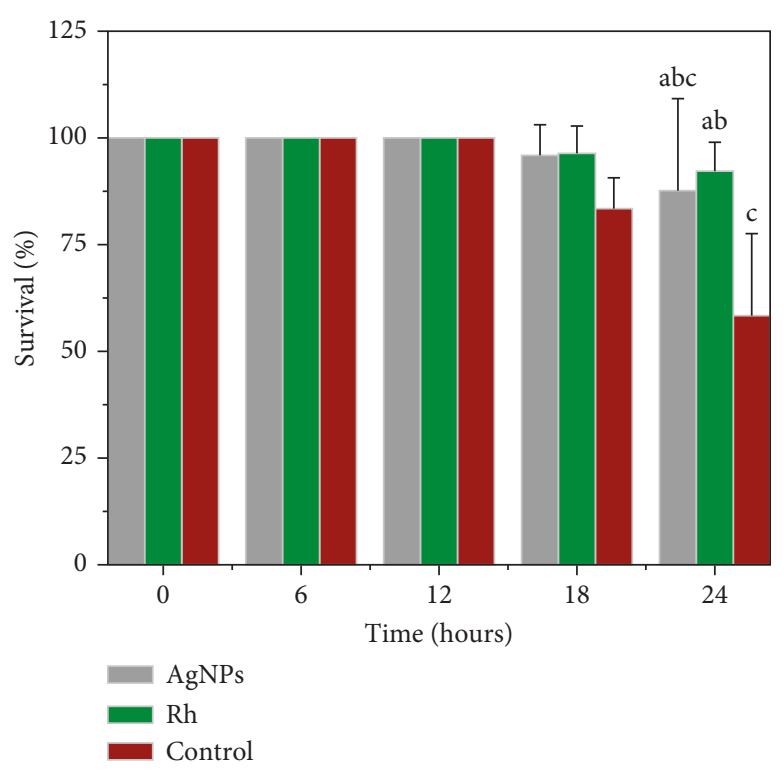

Figure 9: Survival assay of shrimp larvae (Pl-15) infected with $V$. parahaemolyticus.

3.9. Shrimp Prepared for Ultramicrotomy Observation in TEM. Osmium tends to react with double bonds $\mathrm{C}=\mathrm{C}$; this means that it acts on unsaturated lipids and various functional groups that have proteins. This tells us that it manages to cross the membrane between proteins and unsaturated lipids. The fine slices obtained were observed by electron microscopy which showed atrophied hepatopancreatic cells and necrotic areas. The mapping with EDS shows the presence of Ag in tissue. By leading to further amplification, it was not possible to find AgNPs in the tissue (Figures 10(a) and 10(b)).

\section{Conclusion}

Rumex hymenosepalus extract provides a fast and efficient synthesis of AgNPs. Both agents have a relevant antimicrobial activity against $V$. parahaemolyticus. The action 


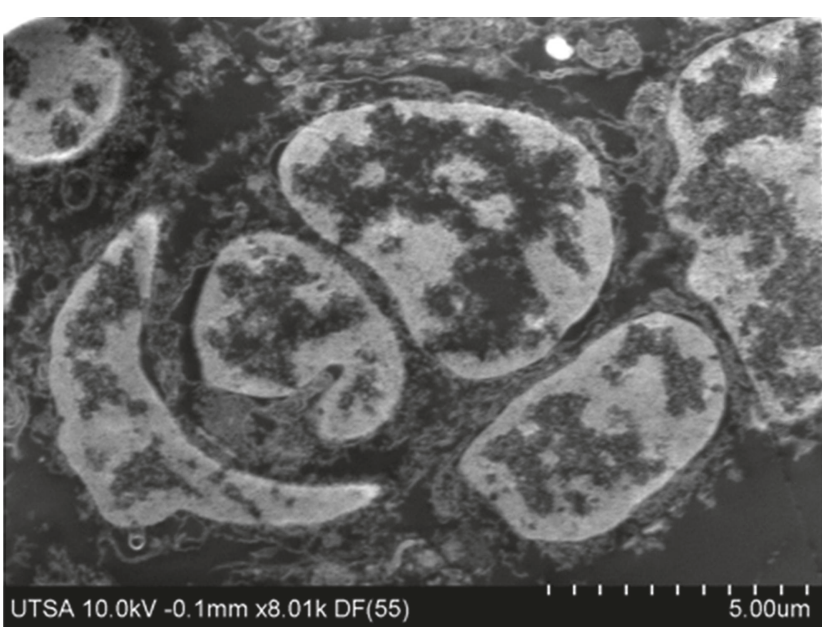

(a)

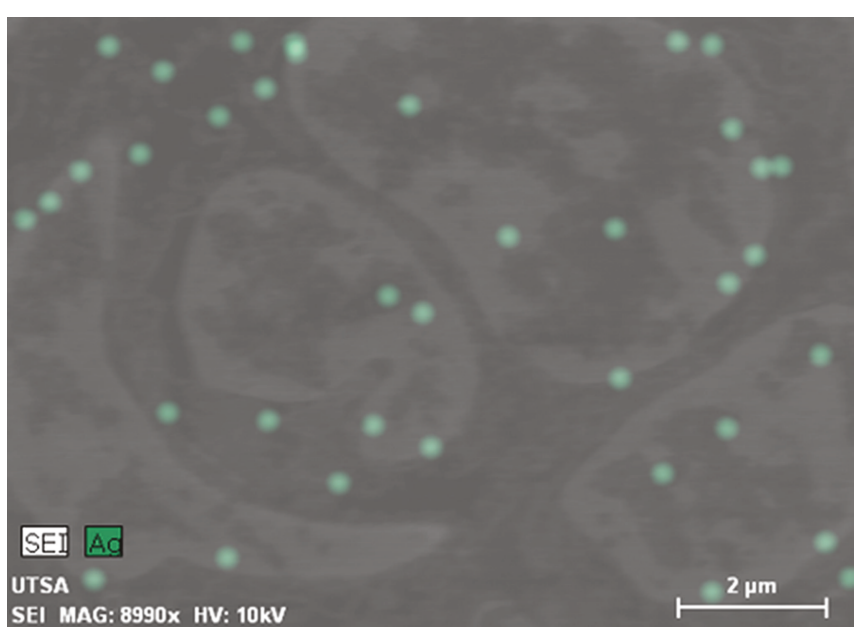

(b)

FIgure 10: (a) Shrimp larva hepatopancreatic tissue with AgNPs and (b) Ag distribution in a sample by EDS.

mechanisms of materials are interaction with bacterial membrane and ROS generation. Artemia viability tests showed that both agents are harmless to the organism, which is beneficial to use it as a carrier of these agents on vibriosis treatment for marine organisms. The survival study of $V$. parahaemolyticus-infected shrimp postlarvae revealed that feeding shrimps with Artemia loaded with both systems (AgNPs and Rh) prior to infection results in a higher survival, compared to the shrimp that did not receive any treatment. In particular, $\mathrm{Rh}$ extract treatment exhibits a significant statistical difference with respect to the control, indicating that treatment with $\mathrm{Rh}$ can be a biosustainable alternative on $V$. parahaemolyticus control and eradication.

\section{Data Availability}

The data used to support the findings of this study are available from the corresponding author upon request.

\section{Conflicts of Interest}

The authors declare that there is no conflict of interest regarding the publication of this paper.

\section{Acknowledgments}

This publication was supported by the University of Sonora and the Professional Development Program (PRODEP) by SEP-México. All authors wish to thank Dr. José Yacamán for the facilities provided in the characterization of the systems by electronic microscopy, as well as to the Kleberg Advanced Microscopy Center of the University of Texas at San Antonio Physics and Astronomy and to the Laboratory of Biomaterials of Physics Department, University of Sonora, for providing the confocal microscopy. F.J. Alvarez-Cirerol thanks to the mixed scholarship number 712583 of CONACYT.

\section{References}

[1] K. M. Barakat, H. S. El-Sayed, and Y. M. Gohar, "Protective effect of squilla chitosan-silver nanoparticles for Dicentrarchus labrax larvae infected with Vibrio anguillarum," International Aquatic Research, vol. 8, no. 2, pp. 179-189, 2016.

[2] M. Sarkheil, I. Sourinejad, M. Mirbakhsh, D. Kordestani, and S. A. Johari, "Antibacterial activity of immobilized silver nanoparticles on TEPA-Den-SiO ${ }_{2}$ against shrimp pathogen, Vibrio sp. Persian1," Aquaculture Research, vol. 48, no. 5, pp. 2120 2132, 2017.

[3] M. Rafique, I. Sadaf, M. S. Rafique, and M. B. Tahir, "A review on green synthesis of silver nanoparticles and their applications," Artificial Cells, Nanomedicine, and Biotechnology, vol. 45, no. 7, pp. 1272-1291, 2017.

[4] G. Taju, D. V. Kumar, S. A. Majeed et al., "Delivery of viral recombinant VP28 protein using chitosan tripolyphosphate nanoparticles to protect the whiteleg shrimp, Litopenaeus vannamei from white spot syndrome virus infection," International Journal of Biological Macromolecules, vol. 107, Part A, pp. 1131-1141, 2018.

[5] X. Hong, L. Lu, and D. Xu, "Progress in research on acute hepatopancreatic necrosis disease (AHPND)," Aquaculture International, vol. 24, no. 2, pp. 577-593, 2016.

[6] M. Latha, M. Priyanka, P. Rajasekar, R. Manikandan, and N. M. Prabhu, "Biocompatibility and antibacterial activity of the Adathoda vasica Linn extract mediated silver nanoparticles," Microbial Pathogenesis, vol. 93, pp. 88-94, 2016.

[7] M. Tello-Olea, S. Rosales-Mendoza, A. I. Campa-Córdova et al., "Gold nanoparticles (AuNP) exert immunostimulatory and protective effects in shrimp (Litopenaeus vannamei) against Vibrio parahaemolyticus," Fish \& Shellfish Immunology, vol. 84, pp. 756-767, 2019.

[8] L. Nunan, D. Lightner, C. Pantoja, and S. Gomez-Jimenez, "Detection of acute hepatopancreatic necrosis disease (AHPND) in Mexico," Diseases of Aquatic Organisms, vol. 111, no. 1, pp. 81-86, 2014.

[9] H. C. Lai, T. H. Ng, M. Ando et al., "Pathogenesis of acute hepatopancreatic necrosis disease (AHPND) in shrimp," Fish \& Shellfish Immunology, vol. 47, no. 2, pp. 1006-1014, 2015. 
[10] P. Li, L. N. Kinch, A. Ray et al., "Acute Hepatopancreatic Necrosis Disease-causing Vibrio parahaemolyticus strains maintain an antibacterial type VI secretion system with versatile effector repertoires," Applied and Environmental Microbiology, vol. 83, no. 13, 2017.

[11] S. L. Williams, R. V. Jensen, D. D. Kuhn, and A. M. Stevens, "Analyzing the metabolic capabilities of a Vibrio parahaemolyticus strain that causes early mortality syndrome in shrimp," Aquaculture, vol. 476, pp. 44-48, 2017.

[12] C. T. Lee, I. T. Chen, Y. T. Yang et al., "The opportunistic marine pathogen Vibrio parahaemolyticus becomes virulent by acquiring a plasmid that expresses a deadly toxin," Proceedings of the National Academy of Sciences of the United States of America, vol. 112, no. 34, pp. 10798-10803, 2015.

[13] S. J. Lin, K. C. Hsu, and H. C. Wang, "Structural insights into the cytotoxic mechanism of Vibrio parahaemolyticus PirA ${ }^{v p}$ and PirB ${ }^{v p}$ toxins," Marine Drugs, vol. 15, no. 12, p. 373, 2017.

[14] O. E. Heuer, H. Kruse, K. Grave, P. Collignon, I. Karunasagar, and F. J. Angulo, "Human health consequences of use of antimicrobial agents in aquaculture," Clinical Infectious Diseases, vol. 49, no. 8, pp. 1248-1253, 2009.

[15] J. Romero, C. Gloria, and P. Navarrete, "Antibiotics in aquaculture - use, abuse and alternatives," in Health and Environment in Aquaculture, p. 159, InTech Open, 2012.

[16] C. H. Kang, Y. G. Kim, S. J. Oh, J. S. Mok, M. H. Cho, and J. S. So, "Antibiotic resistance of Vibrio harveyi isolated from seawater in Korea," Marine Pollution Bulletin, vol. 86, no. 1-2, pp. 261-265, 2014.

[17] C. H. Kang, Y. J. Shin, S. C. Jang et al., "Characterization of Vibrio parahaemolyticus isolated from oysters in Korea: resistance to various antibiotics and prevalence of virulence genes," Marine Pollution Bulletin, vol. 118, no. 1-2, pp. 261266, 2017.

[18] J. Y. Song and B. S. Kim, "Rapid biological synthesis of silver nanoparticles using plant leaf extracts," Bioprocess and Biosystems Engineering, vol. 32, no. 1, pp. 79-84, 2009.

[19] H. Agarwal, S. Venkat Kumar, and S. Rajeshkumar, "A review on green synthesis of zinc oxide nanoparticles - an ecofriendly approach," Resource-Efficient Technologies, vol. 3, no. 4, pp. 406-413, 2017.

[20] E. Rodríguez-León, R. Iñiguez-Palomares, R. Navarro et al., "Synthesis of silver nanoparticles using reducing agents obtained from natural sources (Rumex hymenosepalus extracts)," Nanoscale Research Letters, vol. 8, no. 1, p. 318, 2013.

[21] E. Rodríguez-León, R. A. Íñiguez-Palomares, R. E. Navarro et al., "Silver nanoparticles synthesized with Rumex hymenosepalus extracts: effective broad-spectrum microbicidal agents and cytotoxicity study," Artificial Cells, Nanomedicine, and Biotechnology, vol. 46, no. 6, pp. 1194-1206, 2018.

[22] Y. S. Hii, C. L. Soo, and H. C. Liew, "Feeding of scleractinian coral, Galaxea fascicularis, on Artemia salina nauplii in captivity," Aquaculture International, vol. 17, no. 4, pp. 363-376, 2009.

[23] C. S. Lim, Z. Bachok, and Y. S. Hii, "Effects of supplementary polyunsaturated fatty acids on the health of the scleractinian coral Galaxea fascicularis (Linnaeus, 1767)," Journal of Experimental Marine Biology and Ecology, vol. 491, pp. 1-8, 2017.

[24] H. Hamsah, W. Widanarni, A. Alimuddin, M. Yuhana, M. Z. Junior, and D. Hidayatullah, "Immune response and resistance of Pacific white shrimp larvae administered probiotic, prebi- otic, and synbiotic through the bio-encapsulation of Artemia sp.," Aquaculture International, vol. 27, no. 2, pp. 567-580, 2019.

[25] G. Castro-Mejía, T. Castro-Barrera, J. L. Arredondo-Figueroa, J. Castro-Mejía, and R. De Lara Andrade, "Antibiotics incorporation in Artemia franciscana nauplii, metanauplii, juveniles and adults, and their inhibitory action on Aeromonas hydrophila bacteria," Hidrobiológica, vol. 17, no. 1, pp. 53-60, 2017.

[26] Y. J. Yang and J. Lin, "Solo falta el nombre del trabajo (no lo encontre)," 2005, Patent No. 6,872,386.

[27] F. Hontoria, J. H. Crowe, L. M. Crowe, and F. Amat, "Potential use of liposomes in larviculture as a delivery system through Artemia nauplii," Aquaculture, vol. 127, no. 2-3, pp. 255264, 1994

[28] G. Libralato, "The case of Artemia spp. in nanoecotoxicology," Marine Environmental Research, vol. 101, pp. 38-43, 2014.

[29] M. R. Madhav, S. E. M. David, R. S. S. Kumar et al., "Toxicity and accumulation of copper oxide $(\mathrm{CuO})$ nanoparticles in different life stages of Artemia salina," Environmental Toxicology and Pharmacology, vol. 52, pp. 227-238, 2017.

[30] M. Kos, A. Kahru, D. Drobne et al., "A case study to optimise and validate the brine shrimp Artemia franciscana immobilisation assay with silver nanoparticles: the role of harmonisation," Environmental Pollution, vol. 213, pp. 173-183, 2016.

[31] H. J. An, M. Sarkheil, H. S. Park, I. J. Yu, and S. A. Johari, "Comparative toxicity of silver nanoparticles (AgNPs) and silver nanowires (AgNWs) on saltwater microcrustacean, Artemia salina," Comparative Biochemistry and Physiology Part C: Toxicology \& Pharmacology, vol. 218, pp. 62-69, 2019.

[32] Y. Ozkan, I. Altinok, H. Ilhan, and M. Sokmen, "Determination of $\mathrm{TiO}_{2}$ and $\mathrm{AgTiO}_{2}$ nanoparticles in Artemia salina: toxicity, morphological changes, uptake and depuration," Bulletin of Environmental Contamination and Toxicology, vol. 96, no. 1, pp. 36-42, 2016.

[33] Z. Lu and S. Martel, "Controlled bio-carriers based on magnetotactic bacteria," in TRANSDUCERS 2007 - 2007 International Solid-State Sensors, Actuators and Microsystems Conference, pp. 683-686, Lyon, France, June 2007.

[34] M. Terracciano, L. de Stefano, H. A. Santos et al., "Silica-based nanovectors: from mother nature to biomedical applications," in Algae - Organisms for Imminent Biotechnology, pp. 211-235, InTech Open, 2016.

[35] C. A. Arancibia-Bulnes, R. Peón-Anaya, D. Riveros-Rosas, J. J. Quiñones, R. E. Cabanillas, and C. A. Estrada, "Beam solar irradiation assessment for Sonora, Mexico," Energy Procedia, vol. 49, pp. 2290-2296, 2014.

[36] C. Bellefroid, A. Lechanteur, B. Evrard, and G. Piel, "Lipid gene nanocarriers for the treatment of skin diseases: current stateof-the-art," European Journal of Pharmaceutics and Biopharmaceutics, vol. 137, pp. 95-111, 2019.

[37] A. Qadir, Y. Gao, P. Suryaji et al., "Non-viral delivery system and targeted bone disease therapy," International Journal of Molecular Sciences, vol. 20, no. 3, p. 565, 2019.

[38] D. Medina Félix, J. A. López Elías, Á. I. Campa Córdova et al., "Survival of Litopenaeus vannamei shrimp fed on diets supplemented with Dunaliella sp. is improved after challenges by Vibrio parahaemolyticus," Journal of Invertebrate Pathology, vol. 148, pp. 118-123, 2017.

[39] P. López-León, A. Luna-González, R. Escamilla-Montes et al., "Isolation and characterization of infectious Vibrio 
parahaemolyticus, the causative agent of AHPND, from the whiteleg shrimp (Litopenaeus vannamei)," Latin American Journal of Aquatic Research, vol. 44, no. 3, pp. 470-479, 2016.

[40] I. Wiegand, K. Hilpert, and R. E. W. Hancock, "Agar and broth dilution methods to determine the minimal inhibitory concentration (MIC) of antimicrobial substances," Nature Protocols, vol. 3, no. 2, pp. 163-175, 2008.

[41] J. M. Andrews and for the BSAC Working Party on Susceptibility Testing, "BSAC standardized disc susceptibility testing method," Journal of Antimicrobial Chemotherapy, vol. 48, Supplement_1, pp. 43-57, 2001.

[42] P. Siritongsuk, N. Hongsing, S. Thammawithan et al., "Twophase bactericidal mechanism of silver nanoparticles against Burkholderia pseudomallei," Plos One, vol. 11, no. 12, article e0168098, 2016.

[43] S. A. Johari, K. Rasmussen, M. Gulumian et al., "Introducing a new standardized nanomaterial environmental toxicity screening testing procedure, ISO/TS 20787: aquatic toxicity assessment of manufactured nanomaterials in saltwater lakes using Artemia sp. nauplii," Toxicology Mechanisms and Methods, vol. 29, no. 2, pp. 95-109, 2019.

[44] O. El-Shahaby, M. El-Zayat, E. Salih, I. M. El-Sherbiny, and F. M. Reicha, "Evaluation of antimicrobial activity of water infusion plant-mediated silver nanoparticles," Journal of Nanomedicine \& Nanotechnology, vol. 4, no. 4, 2013.

[45] S. Agnihotri, S. Mukherji, and S. Mukherji, "Size-controlled silver nanoparticles synthesized over the range 5-100 nm using the same protocol and their antibacterial efficacy," RSC Advances, vol. 4, no. 8, pp. 3974-3983, 2014.

[46] N. Durán, M. Durán, M. B. de Jesus, A. B. Seabra, W. J. Fávaro, and G. Nakazato, "Silver nanoparticles: a new view on mechanistic aspects on antimicrobial activity," Nanomedicine: Nanotechnology, Biology and Medicine, vol. 12, no. 3, pp. 789-799, 2016.

[47] K. Satyavani, S. Gurudeeban, T. Ramanathan, and T. Balasubramanian, "Biomedical potential of silver nanoparticles synthesized from calli cells of Citrullus colocynthis (L.) Schrad," Journal of Nanobiotechnology, vol. 9, no. 1, p. 43, 2011.

[48] R. Majumdar, B. G. Bag, and N. Maity, "Acacia nilotica (Babool) leaf extract mediated size-controlled rapid synthesis of gold nanoparticles and study of its catalytic activity," International Nano Letters, vol. 3, no. 1, p. 53, 2013.

[49] A. Panáček, L. Kvítek, M. Smékalová et al., "Bacterial resistance to silver nanoparticles and how to overcome it," Nature Nanotechnology, vol. 13, no. 1, pp. 65-71, 2018.

[50] Y.-K. Kim and L. L. McCarter, "Analysis of the polar flagellar gene system of Vibrio parahaemolyticus," Journal of Bacteriology, vol. 182, no. 13, pp. 3693-3704, 2000.

[51] L. Zhang, X. Zhang, H. Zhang et al., "Preparation of monoclonal antibodies against flagellin core protein of Vibrio parahaemolyticus and its activity analysis," Xi Bao Yu Fen Zi Mian Yi Xue Za Zhi=Chinese Journal of Cellular and Molecular Immunology, vol. 29, no. 7, pp. 734-738, 2013.

[52] S. Zhu, S. Kojima, and M. Homma, "Structure, gene regulation and environmental response of flagella in Vibrio," Frontiers in Microbiology, vol. 4, p. 410, 2013.

[53] S. Palanisamy, R. Anjali, P. Rajasekar, E. Kannapiran, B. Vaseeharan, and N. M. Prabhu, "Synthesis and distribution of bioinspired silver nanoparticles using spirulina extract for control of Vibrio parahaemolyticus infection in aquaculture," Asian Journal of Chemistry, vol. 29, no. 4, pp. 857-863, 2017.

[54] B. Vaseeharan, P. Ramasamy, and J. C. Chen, "Antibacterial activity of silver nanoparticles (AgNps) synthesized by tea leaf extracts against pathogenic Vibrio harveyi and its protective efficacy on juvenile Feneropenaeus indicus," Letters in Applied Microbiology, vol. 50, no. 4, pp. 352-356, 2010.

[55] S. A. Johari, M. R. Kalbassi, and I. J. Yu, "Inhibitory effects of silver zeolite on in vitro growth of fish egg pathogen, Saprolegnia sp.," Journal of Coastal Life Medicine, vol. 2, no. 5, pp. 357-361, 2014.

[56] S. A. Johari, M. R. Kalbassi, M. Soltani, and I. J. Yu, “Application of nanosilver-coated zeolite as water filter media for fungal disinfection of rainbow trout (Oncorhynchus mykiss) eggs," Aquaculture International, vol. 24, no. 1, pp. 23-38, 2016.

[57] T. Nakayama, M. Ichiba, M. Kuwabara, K. Kajiya, and S. Kumazawa, "Mechanisms and structural specificity of hydrogen peroxide formation during oxidation of catechins," Food Science and Technology Research, vol. 8, no. 3, pp. 261267, 2002.

[58] H. Arakawa, M. Maeda, S. Okubo, and T. Shimamura, "Role of hydrogen peroxide in bactericidal action of catechin," Biological and Pharmaceutical Bulletin, vol. 27, no. 3, pp. 277-281, 2004.

[59] M. Nakayama, N. Shigemune, T. Tsugukuni, H. Tokuda, and T. Miyamoto, "Difference of EGCg adhesion on cell surface between Staphylococcus aureus and Escherichia coli visualized by electron microscopy after novel indirect staining with cerium chloride," Journal of Microbiological Methods, vol. 86, no. 1, pp. 97-103, 2011.

[60] L. G. Xiong, Y. J. Chen, J. W. Tong et al., "Tea polyphenol epigallocatechin gallate inhibits Escherichia coli by increasing endogenous oxidative stress," Food Chemistry, vol. 217, pp. 196-204, 2017.

[61] M. Nakayama, K. Shimatani, T. Ozawa et al., "A study of the antibacterial mechanism of catechins: isolation and identification of Escherichia coli cell surface proteins that interact with epigallocatechin gallate," Food Control, vol. 33, no. 2, pp. 433-439, 2013.

[62] M. Vestergaard and H. Ingmer, "Antibacterial and antifungal properties of resveratrol," International Journal of Antimicrobial Agents, vol. 53, no. 6, pp. 716-723, 2019.

[63] D. Hwang and Y. H. Lim, "Resveratrol antibacterial activity against Escherichia coli is mediated by Z-ring formation inhibition via suppression of FtsZ expression," Scientific Reports, vol. 5, no. 1, article 10029, 2015.

[64] L. L. Wang, C. Hu, and L. Q. Shao, "The antimicrobial activity of nanoparticles: present situation and prospects for the future," International Journal of Nanomedicine, vol. 12, pp. 1227-1249, 2017.

[65] Y. Y. Loo, Y. Rukayadi, M. A. R. Nor-Khaizura et al., "In vitro antimicrobial activity of green synthesized silver nanoparticles against selected gram-negative foodborne pathogens," Frontiers in Microbiology, vol. 9, article 1555, 2018.

[66] E. D. Cavassin, L. F. P. de Figueiredo, J. P. Otoch et al., "Comparison of methods to detect the in vitro activity of silver nanoparticles (AgNP) against multidrug resistant bacteria," Journal of Nanobiotechnology, vol. 13, no. 1, p. 64, 2015.

[67] J. Wang, L. Tang, P. Somasundaran et al., "Highly effective antibacterial activity by the synergistic effect of three 
dimensional ordered mesoporous carbon-lysozyme composite," Journal of Colloid and Interface Science, vol. 503, pp. 131-141, 2017.

[68] V. S. Radhakrishnan, M. K. Reddy Mudiam, M. Kumar, S. P. Dwivedi, S. P. Singh, and T. Prasad, "Silver nanoparticles induced alterations in multiple cellular targets, which are critical for drug susceptibilities and pathogenicity in fungal pathogen (Candida albicans)," International Journal of Nanomedicine, vol. 13, pp. 2647-2663, 2018.

[69] M. Hartmann, M. Berditsch, J. Hawecker, M. F. Ardakani, D. Gerthsen, and A. S. Ulrich, "Damage of the bacterial cell envelope by antimicrobial peptides gramicidin S and PGLa as revealed by transmission and scanning electron microscopy," Antimicrobial Agents and Chemotherapy, vol. 54, no. 8, pp. 3132-3142, 2010.

[70] N. Yin, R. Gao, B. Knowles et al., "Formation of silver nanoparticles by human gut microbiota," Science of the Total Environment, vol. 651, pp. 1489-1494, 2019. 


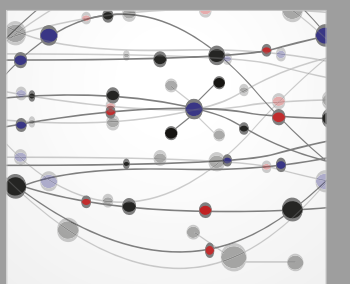

The Scientific World Journal
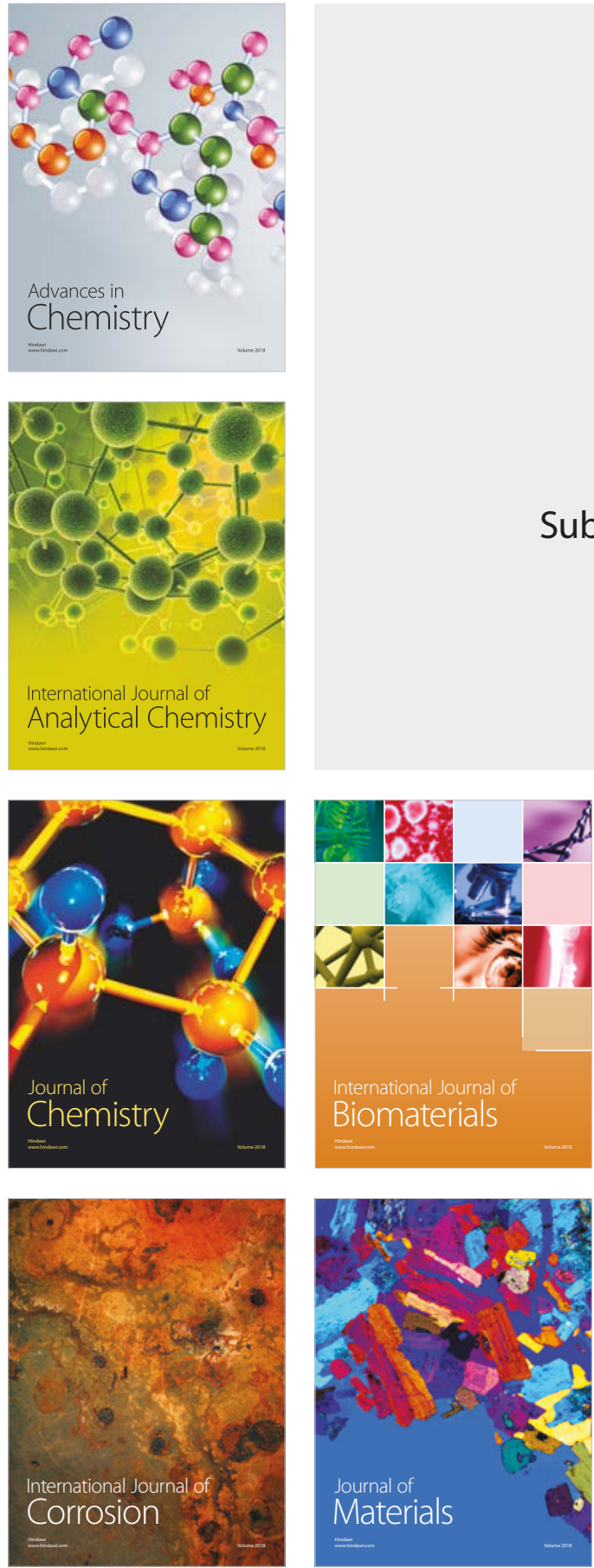

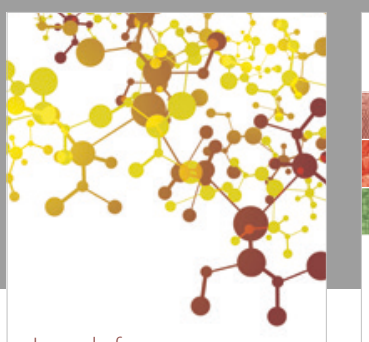

Journal of

Applied Chemistry
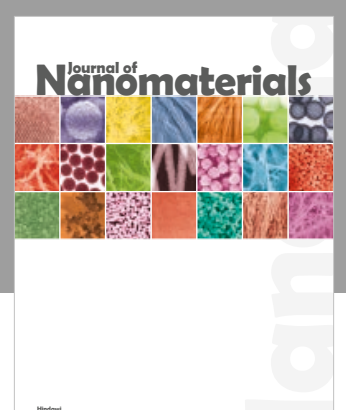

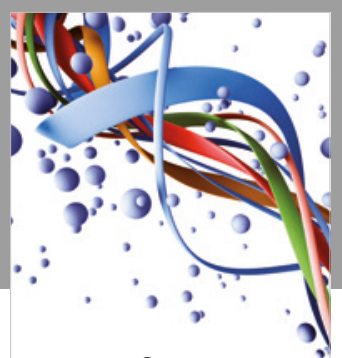

Scientifica

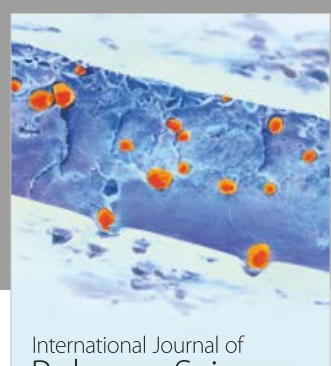

Polymer Science

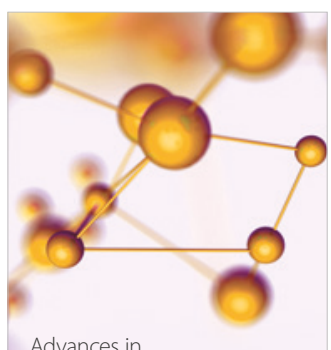

Physical Chemistry
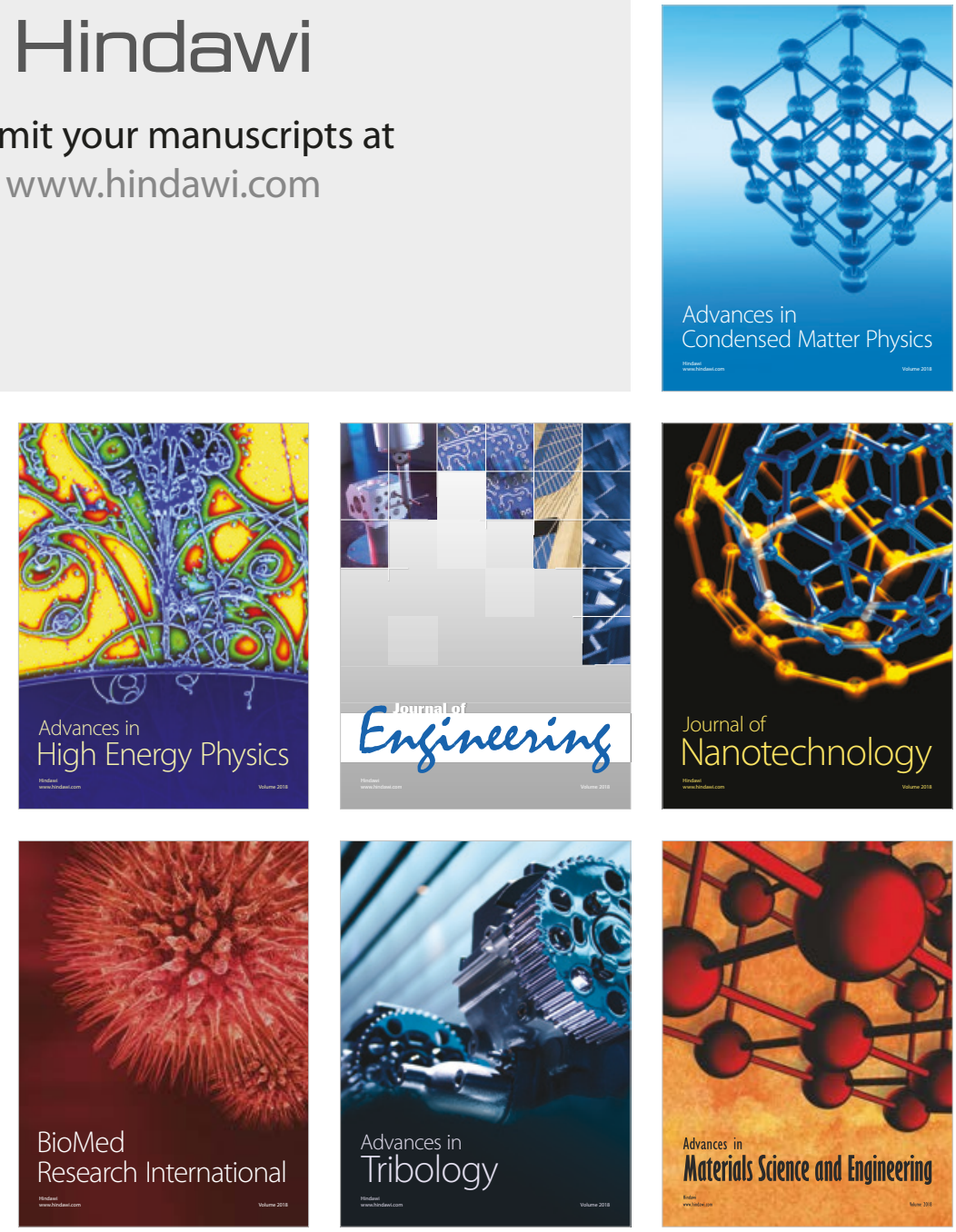